\title{
IMPROVEMENT OF KENTUCKY BLUEGRASS THROUGH SELECTION AND BREEDING
}

JULY 1972 - NUMBER 25

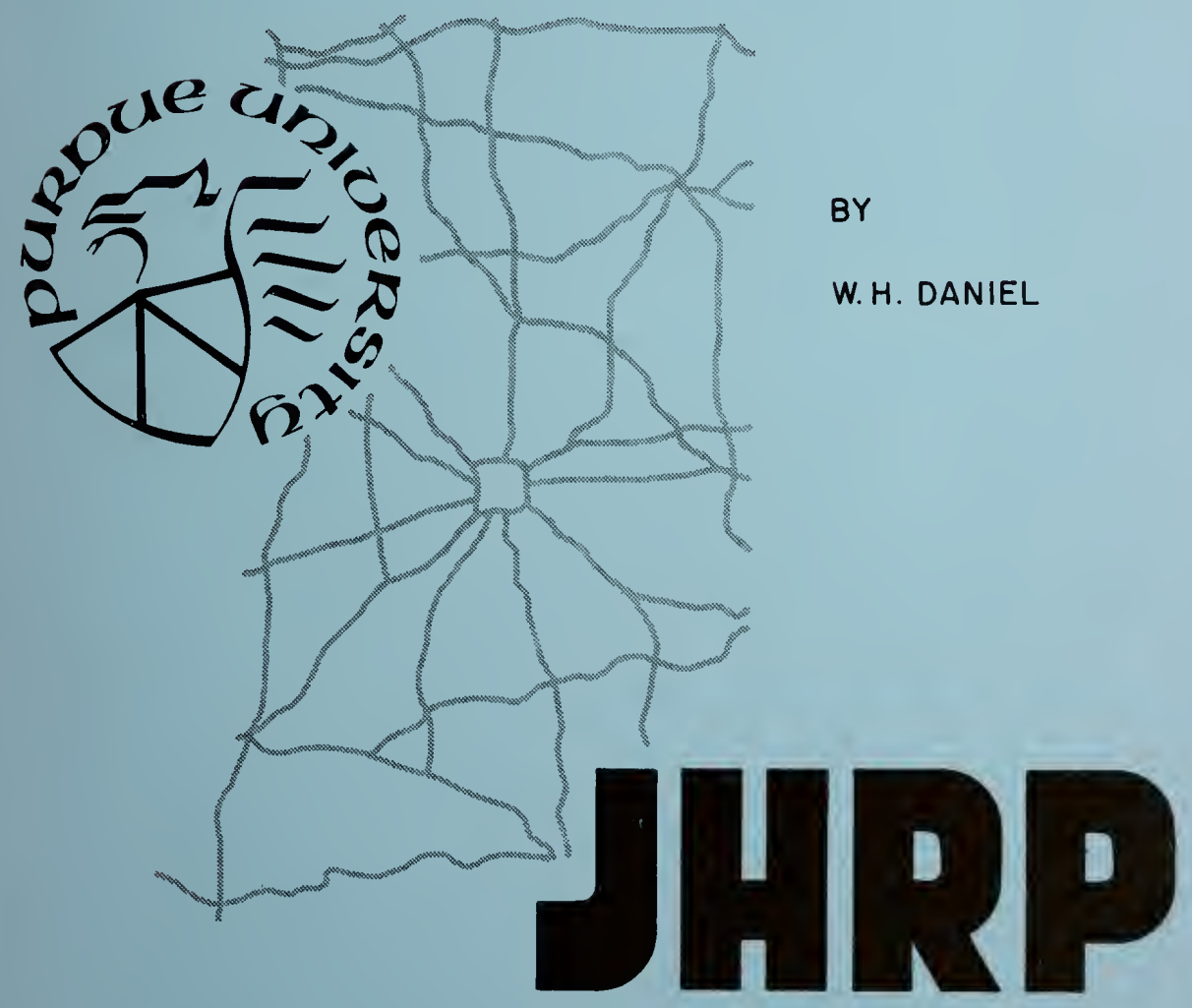

JOINT HIGHWAY RESEARCH PROJECT PURDUE UNIVERSITY AND

INDIANA STATE HIGHWAY COMMISSION 

Final Report

IMPROVEMENT OF KENTUCKY BLUEGRASS THROUGH SELECTION

AND BREEDING

TO: J.F. Mclaughlin, Director

Joint Highway Research Project

FROM: H. L. Michael, Associate Di rector

Joint Highway Research Project

July 26, 1972
Project: $\quad$ C-36-48C

File: $\quad 9-5-3$

The attached Final Report "Improvement of Kentucky Bluegrass Through Selection and Breeding" is submitted as fulfillment of the objectives of Part I of the HPR Part II Research Study "Research in Roadside Development and Maintenance". The Report has been authored by the principal investigator, Dr. William H. Daniel.

The Study has progressed to the point where thirteen (13) selections of bluegrass have been made. The final selection of the fewer types to be finally selected for seed increase and further testing is planned as the initial portion of a new HPR Research Study titled "Superior Bluegrasses for Roadside Turf".

This Report is submitted for acceptance. It will also be submitted to the ISHC and FHWA for review, comment and acceptance as fulfillment of the objectives of Part I of the referenced HPR Study.

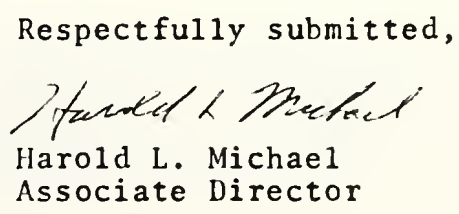

HLM : ms

cc: W. L. Dolch

R. L. Eskew

M. L. Hayes

W. H. Goetz

C. W. Lovel1

M. J. Gutzwiller

G. W. Marks

R. D. Miles

G. K. Hallock

J. W. Miller

R. H. Harrell

G. T. Satterly

C. F. Scholer

M. B. Scott

J. A. Spooner

N. W. Steinkamp

H. R. J. Walsh

E. J. Yoder 
Digitized by the Internet Archive in 2011 with funding from

LYRASIS members and Sloan Foundation; Indiana Department of Transportation 
Final Report

IMPROVEMENT OF KENTUCKY BLUEGRASS THROUGH SELECTION

AND BREEDING

by

W. H. Danie1

Professor

Department of Agronomy

Joint Highway Research Project

Project No.: C $-36-48 \mathrm{C}$

File No.: $9-5-3$

Prepared as Part of an Investigation

Conducted by

Joint Highway Research Project

Engineering Experiment Station

Purdue University

In cooperation with the

Indiana State Highway Commission

and the

U.S. Department of Transportation

Federal Highway Administration

The contents of this report reflect the views of the author who is responsible for the facts and the accuracy of the data presented herein. The contents do not necessarily reflect the official views or policies of the Federal Highway Administration. This report does not constitute a standard, specification, or regulation.

Purdue University

West Lafayette, Indiana

July 26, 1972 
TABLE OF CONTENTS

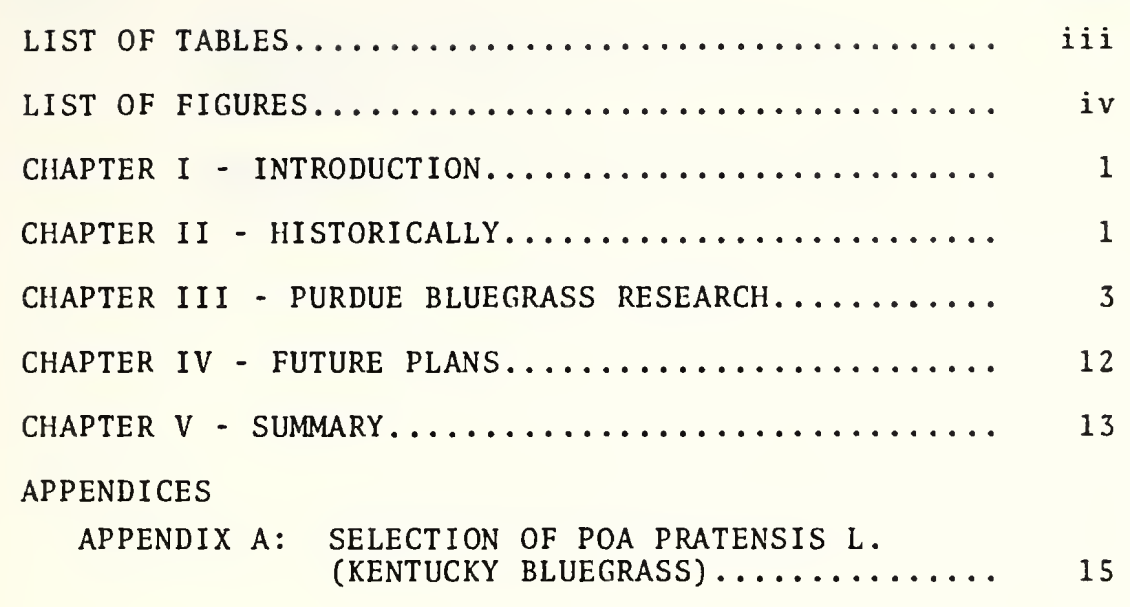




\section{LIST OF TABLES}

Table

$\underline{\text { Page }}$

1

Selections Used in First Roadside Planting in Median of I-65 at Highway

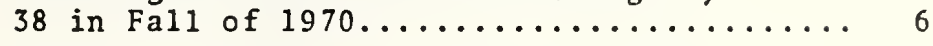

Bluegrass Performance Data for 1971-

1972. East-West Slope Roadside Plots...... 9 


\section{LIST OF FIGURES}

Figure

Page

1 Variable Seedhead lleight And Coloring

of Second Year on Some Bluegrass

Selections Grown at Lower Nitrogen

Leve1s, Agronomy Farm, 10B3, 1971....... 5

2 Sodding and Seeding Experiment Started in September, 1970 on Median of $\mathrm{I}-65$ at Highway 38. A very difficult site -

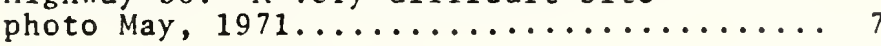

3 Variations in Seedhead Height of Sodded Portion of Median of I-65 at Highway 38 Experiment. Height was $14^{\prime \prime}$ Down to 6 "

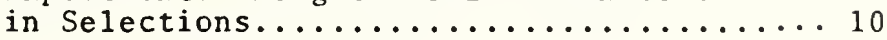

4 Experiment on East facing Slope of I-65 South of Highway 28 Showing Highway Mix in Foreground, Ryegrass Strip Beyond Person, and Experimentation Bluegrass

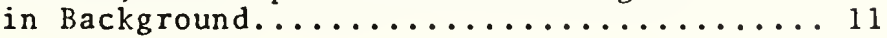




\section{Introduction}

The purpose of this project was to select Kentucky bluegrass varieties whose characteristics would meet the rigid requirements of roadside turf. Requirements considered most important include: increased rhizome spread - for quick establishment and long term maintenance of sloping areas; low growth characteristics to reduce mowing frequency and plant resistance to common turf disease.

The low growth habit is one of the most important characteristics. There are over 600 miles of Interstate Highway systems in Indiana, with approximately 18 acres per linear mile, giving a total of 11,000 acres which need to be mowed 4 times each year. At a mowing cost of $\$ 10.00$ per acre, an estimated cost per year is $\$ 440,000$. A $50 \%$ reduction in mowing frequency requirements would amount to annual savings of $\$ 220,000$.

This project was undertaken with the knowledge that a superior turfgrass would need only out-perform combinations of Kentucky bluegrass, tall fescue, perennial and annual rye, and be propagated by seed.

\section{Historically}

It has been observed that through natural adaptation of species, bluegrass becomes the more dominant grass existing along roadsides in Indiana. Throughout the cool, humid region, its persistence illustrates its adaptability to this climate. The inability of available varieties to develop into an established turf has been the source of maintenance 
problems throughout the many years of highway roadside development. In addition, the specifications for tall fescue, annual and perennial rye, and common Kentucky bluegrass for roadsides presents mowing and erosion problems which need solving.

For many years common Kentucky bluegrasses, either Midwestern, Northwestern, or foreign grown, have been used in roadside plantings. Improved varieties were gradually developed. In 1950, Merion, with leafspot resistance, but susceptible to rust, matforming, and requiring high fertility, was released. Since 1960 , Newport, which produces heavy seed yields, has seen rapid increase in seed production, then a decreased demand. Delta bluegrass was selected in 1950. It has been increased slowly. It is much like common Kentucky, but with some extra seedling vigor. Park bluegrass from Minnesota was another release made about 1960 . These grasses found their greatest acceptance as blends in bluegrass lawns. Other bluegrass varieties have found their way into the market since 1960. These have appeared only recently and include such varieties as: Fylking, Pennstar, Sydsport, Sodco, Nugget, Baron, Windsor, A-20, A-34, Others are in production and will be available in 1973 .

Not one of these improved varieties was selected for roadside use, and no one grass had any special value for roadsides. Some require heavier fertilization, have yellow leaf color, fine leaves which fallover quickly, or produce excess, stemmy seedheads. Selections were not made for rapid establishment, ability to compete, low seedhead height, 
and disease resistance, all of the characteristics of a good highway turf.

\section{Purdue Bluegrass Research}

A very diverse, sexual parent of Kentucky bluegrass, Poa pratensis, existing in the turf research program at Purdue since 1965, had provided over 100 different, variable seedlings. Among these were several very fine, dark-green types, which could serve well as a lawn grass. At the other extreme, however, were several very coarse, wide-spreading, vigorous seedlings with many characteristics perferred for highway use. These latter grasses have been the bas is for selection of improved bluegrasses, demonstrating low growth, abundant and vigorous rhizome and tillering, and disease resistance.

Intensive activity in selecting and propagating preferred types was started in 1965 by T. P. Riordan and Dr. W. II. Daniel as a highway research roadside project. Selections were put out as space plantings every year since 1965. These served as the basis for the screening of over 12,000 individual bluegrass plants for characteristics that would provide a superior roadside bluegrass. Data from the 1965 , 1966, and 1967 screening program is included in Progress Report, "Research on Roadside Development and Maintenance, Part 1. Bluegrass Research", by Danie1, W. H., and T. P. Riordan, dated 1968 . 
Throughout 1969 and into 1972, further research applicable to roadside bluegrass development was carried out. Investigations were made into the chromosome numbers of selected bluegrasses. The objective was to determine whether the number of chromosomes in a bluegrass plant was an indicator of mode of reproduction. The purpose of this objective was to seek a method that would permit more efficient selection techniques based on the assumption that low chromosome numbers would be associated with apomictic reproduction. Apomictic reproduction (non-sexual) of bluegrass varieties produces pregeny that remain true to type. Thus, if a superior plant is found it may remain superior through apomixis. Results showed that when the chromosome number of selections was compared to mode of reproduction there was little apparent relationship between determination of chromosome numbers and mode of reproduction. Therefore, the efficiency of selection to be obtained from identification of chromosome number was not a valid criteria. Individual cell counts ranged from 37 to 71 , with the mean for selections ranging from 40 to 68 .

The field research completed in 1968, 1969, and 1970 is reported in an attached Appendix "Selection of Poa pratensis L., (Kentucky bluegrass)" by T. P. Riordan. The data in this report as well as the earlier Progress Report was based on the evaluation of over 12,000 individual Kentucky bluegrass seedlings which were rated and measured with the goal of selection of types adaptable to roadside utilization.

All plants were rated for rhizome spread - the most important single desired feature - and mature leaf height 


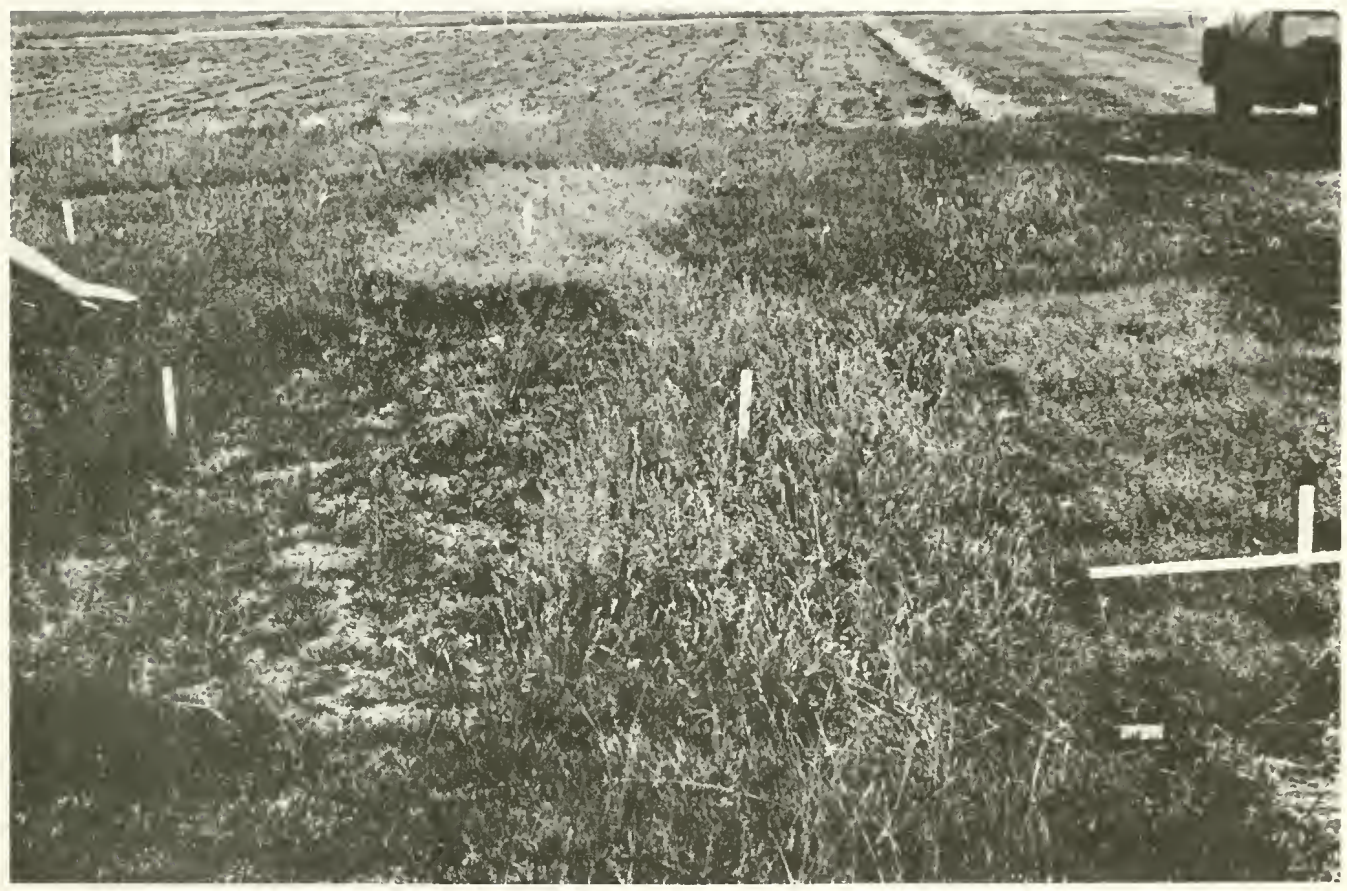

Figure 1. Variable Seedhead Height and Coloring of Second Year on Some Bluegrass Selections Grown at Lower Nitrogen Levels, Agronomy Farm, 10B3, 1971. 
was measured to classify for lower growing types. Other ratings and measurements included in experiment 1 were: rust resistance, leaf color, winter survival, and panicle characteristics. In experiment 2, leaf color and panicle characteristics; and in experiment 3 , rust resistance, leaf color, seed germination and seedling characteristics were recorded.

Superior bluegrasses with low growth and vigorous spread were planted on State Road 38 and Interstate 65 in fall of 1970. Also, the evaluation of new progeny as they developed continued in the breeder field space plantings. Roadside plantings were made as sod, and for some selections as seed. Bluegrasses included in this first roadsidc planting are included in Table 1 .

Table 1. Selections (from 12,000 measured) used in first roadside planting in median of $\mathrm{I}-65$ at Hy. 38 in fall of 1970 .

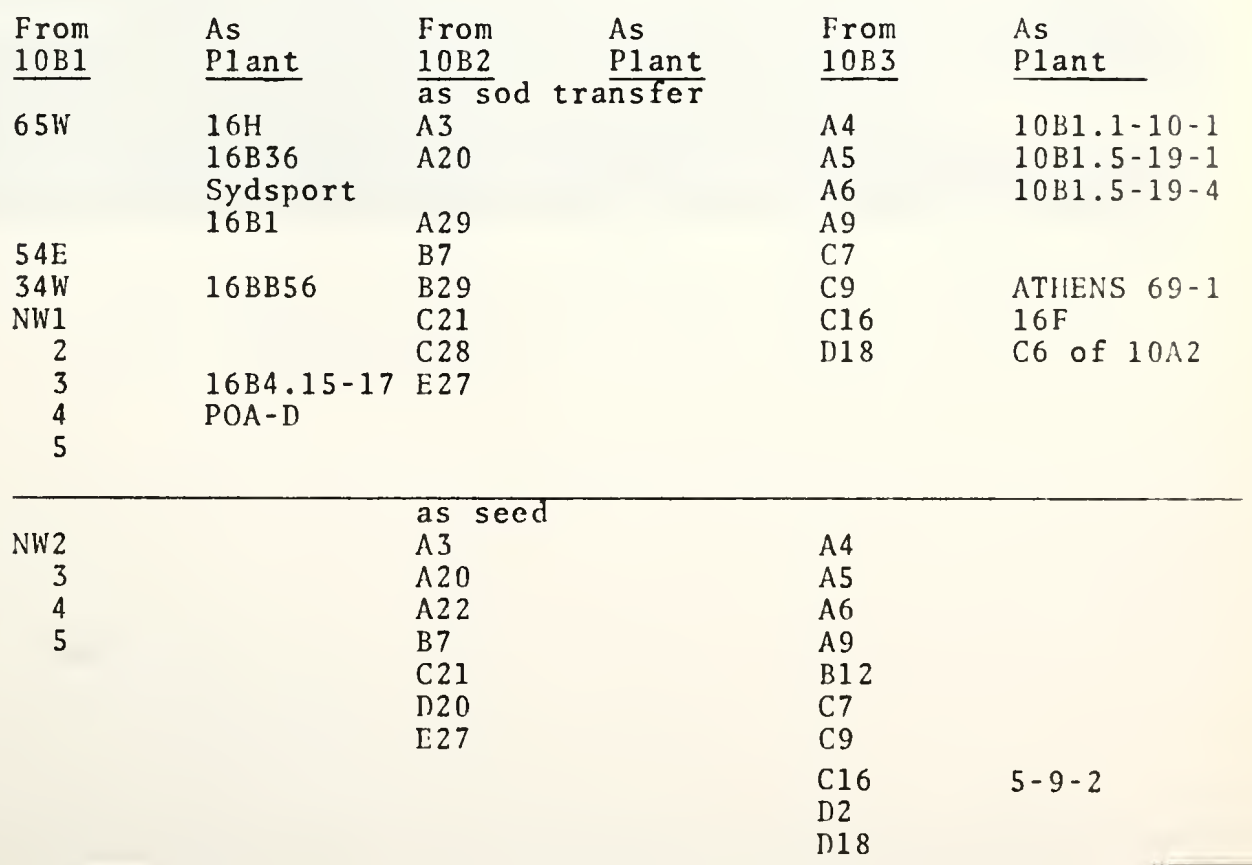




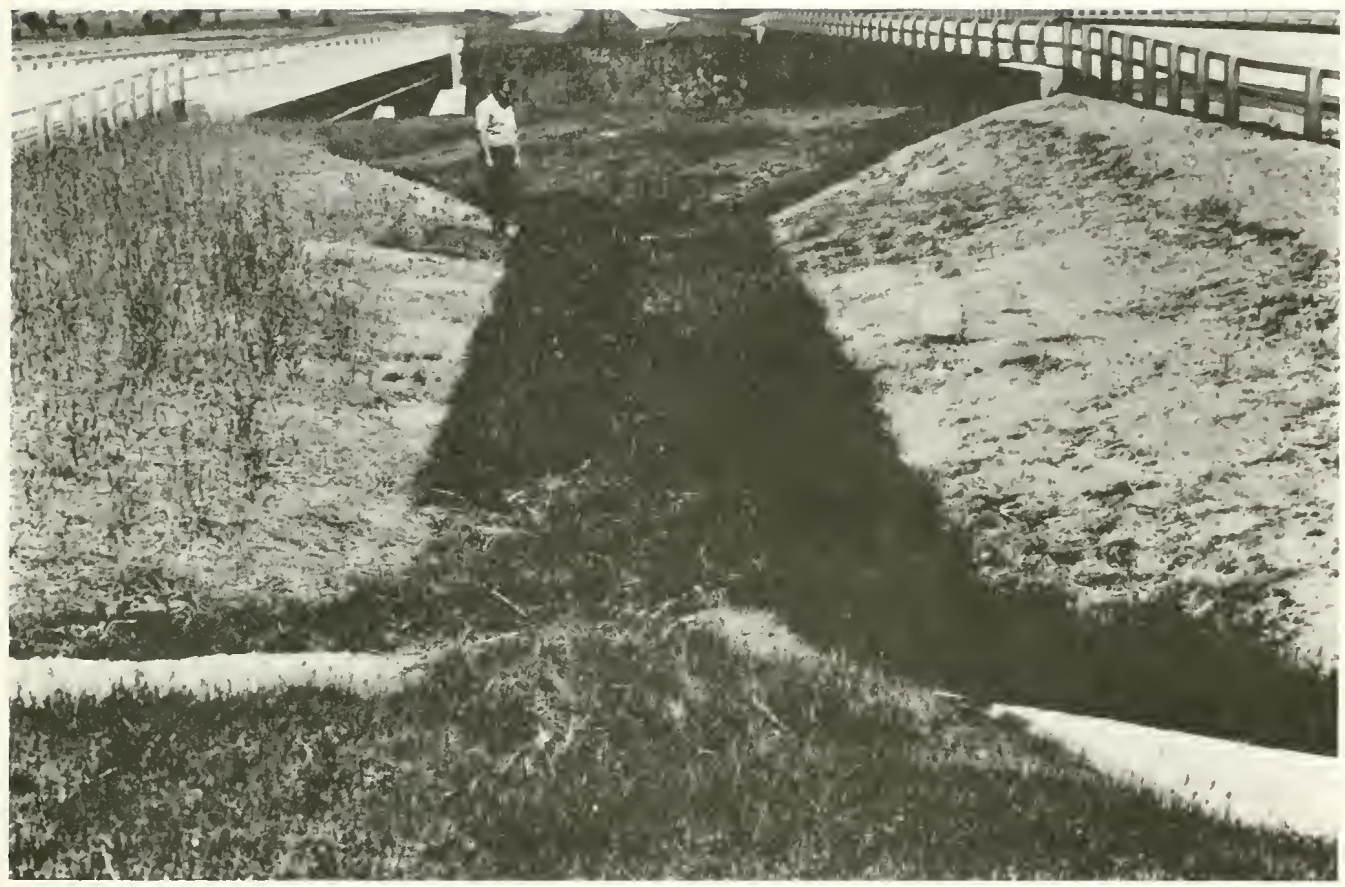

Figure 2. Sodding and Seeding Experiment Started In September, 1970 on Median of I-65 at Hy. 38. A Very Difficult Site - Photo May, 1971. 
Ten superior varieties were selected from the original 31 in October, 1971. Selections were made on the basis of superior low growth, vigorous spread, under low nutrition, and disease resistance. Second year field observations were continued in 1972 to confirm original selections of superior varieties. By August of 1972 superior varieties numbered 13 . The final selection from these 13 will be made in the springsummer of 1973. Those varieties considered as superior highway grasses will then be harvested for seed production beginning in 1973. Part of this seed increase should then be used for expanded experimentation in larger plots at more extensive locations on highway roadsides in Indiana. The remainder of harvested seed will be reserved as a basis for breeder seed and increase.

Twenty-five new bluegrasses were planted in the greenhouse in September 1971. These grasses were selected from the field breeding program, and highway roadside plantings. They were rated for seed germination, seedling growth, and disease resistance throughout the winter and spring of 1971-1972. Those types showing superior characteristics were then transplanted in the field in summer of 1972. Seed was harvested and stored for future roadside testing.

Also, in September 1971, both experimental and improved commercial releases of bluegrasses, plus two varietics of improved perennial ryegrass, were planted in large area plots. These plots are located on east and on west facing slopes along Interstate 65,1 mile south of State Road 28 . Soils were analyzed and adequate fertility levels established. 
Seed planted at 1 b./1,000 sq. ft. due to 1 imited seed quantity available. Performance data for these grasses is recorded in Table 2 .

Table 2. Bluegrass performance data for 1971-72. East-west slope roadside plots.

West facing slope

Nugget bluegrass

Baron bluegrass

Pennstar bluegrass

Fylking bluegrass

Sydsport bluegrass

Dosco bluegrass

Compas ryegrass

Compas rye \& Sydsport

Compi rye + Sydsport

Compi rye alone

* Average of 5 ratings.

**Average of 8 ratings.

\section{East facing slope}

Nugget variety

Baron Variety

Pennstar variety

Fylking variety

Sydsport

Sodco variety

10.B3-B12. experimental

$9 \mathrm{Al}-\mathrm{C} 4(\mathrm{f})$

$9 \mathrm{~A} 1-\mathrm{C} 7$

$10 B 3-A 11$

$10 \mathrm{~B} 2-\mathrm{B} 16$

$9 \mathrm{~A} 1-\mathrm{C} 6$

$9 \mathrm{~A} 1-\mathrm{C} 4$

State highway mix

Sodco \& Compas rye
Best $10 \%$ P10t

$6 / 20$ st and

95

90

40

80

60

90

89

--

$-$

90
79

56

53

58

54

58

78

$--$

$-\cdot$

79

Total plot area $6 / 20 \% \operatorname{stand} \frac{8 / 72 * *}{}$

60

30

20

50

20

75

40

- -

$-\cdot$

40

56

41

48

42

45

44

57

-.

-

60
75

70

30

30

10

50

20

20

50

50

30

20

20

25

25
70 *

70

30

40

20

60

20

20

30

30

40

30

20

35

45

*Average of 3 ratings. 


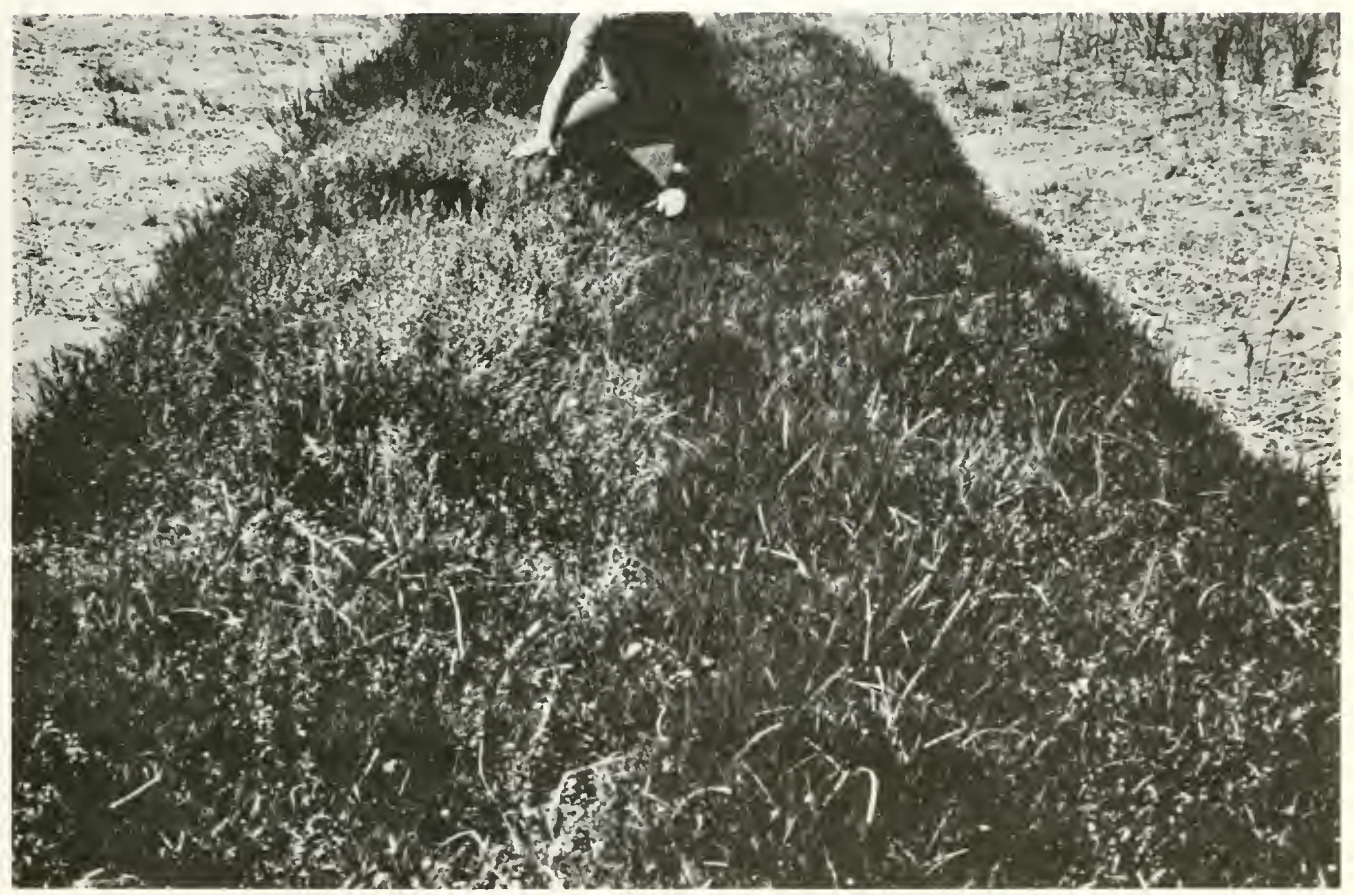

Figure 3. Variations in Seedhead Height of Sodded Portion of Median of I-65 at Hy. 38 Experiment. Height was $14^{\prime \prime}$ down to $6^{\prime \prime}$ in Selections. 


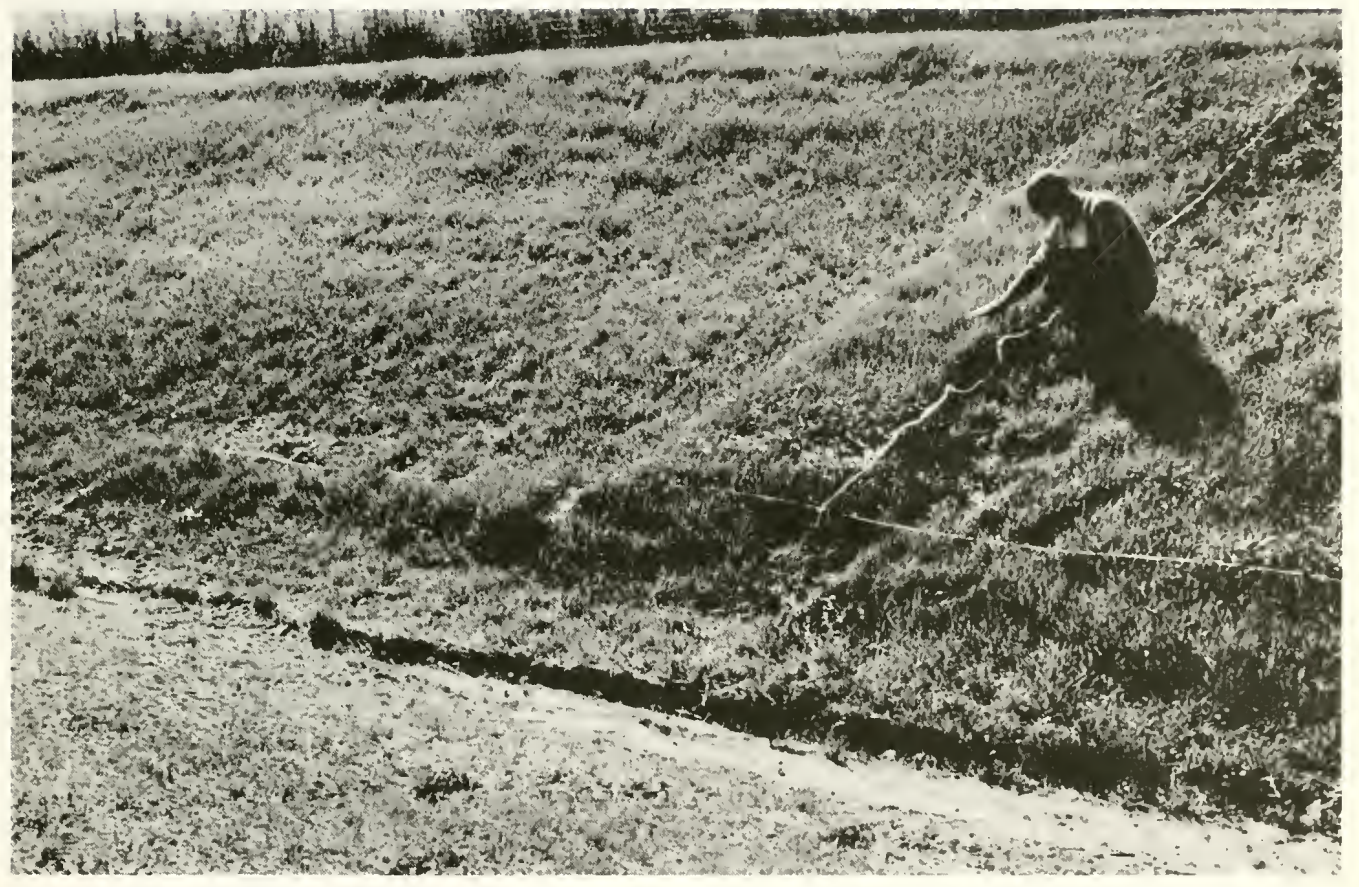

Figure 4. Experiment on East Facing Slope of I-65 South of Hy. 28 Showing Highway Mix in Foreground, Ryegrass Strip Beyond Person, and Experimentation Bluegrasses in Background. 


\section{Future P1ans}

The above grasses planted at the Agronomy Farm as well as those planted at State Road 38 and Interstate 65 , continue under observation and selection for superior observations with continuance through 1972 and 1973. Those grasses finally selected in 1973 should be planted for seed increase in September 1973. This seed increase should then be used to plant larger plots at highway roadside locations throughout Indiana. Seed increase should also continue so that adequate breeders seed will be available for contract seed production following final selection of superior varieties.

Listed below are those bluegrass types showing best performance in highway test plots by August, 1972. Out of these selections will come the bluegrasses to be recommended for seed increase and expanded testing.

\section{Bluegrass code, In.}

$\begin{array}{ll}\text { 1. } & 10 \mathrm{~B} 2-\mathrm{B} 7 \\ \text { 2. } & 10 \mathrm{~B} 3-\mathrm{A} 4 \\ 3 . & 10 \mathrm{~B} 2-\mathrm{A} 3 \\ \text { 4. } & 10 \mathrm{~B} 2-\mathrm{E} 27 \\ \text { 5. } & 10 \mathrm{~B} 3-\mathrm{A} 5 \\ \text { 6. } & \text { Sydsport* } \\ \text { 7. } & 10 \mathrm{~B} 3-\mathrm{A} 6 \\ \text { 8. } & 10 \mathrm{~B} 1-\mathrm{No} 5 \\ \text { 9. } & 10 \mathrm{~B} 3-\mathrm{C}-16 \\ \text { 10. } & 10 \mathrm{~B} 1-\mathrm{No} 2 \\ 11 . & 10 \mathrm{~B} 3-\mathrm{A}-9 \\ 12 . & 10 \mathrm{~B} 3-\mathrm{C}-7 \\ 13 . & 10 \mathrm{~B} 1-\mathrm{No} 1\end{array}$

*Sydsport is a new variety from Sweden, used because of its superior performance in turf trials at Purdue and in Europe. 


\section{Summary}

This report includes an introduction to the existing highway problems and costs, as well as proposed solutions. The development of improved-adapted bluegrasses, which would contribute to more uniform turf, lower plant height, thus less mowing frequency required, would provide a solution to highway maintenance problems, and offer a reduction in maintenance costs.

A Progress Report, "Improvement of Kentucky Bluegrass Through Breeding and Selection", by W. H. Daniel and T. P. Riordan, was submitted September, 1968. This report identified the following characteristics required of a good roadside bluegrass:

$$
\begin{aligned}
& \text { 1. Low panicle height } \\
& \text { 2. Low leaf height } \\
& \text { 3. Abundant and vigorous rhizome growth } \\
& \text { 4. Disease resistance } \\
& \text { 5. Good color }
\end{aligned}
$$

Initial screening in the above report selected bluegrass plants meeting these characteristics in one or more than one of the criteria. Thus, parent material was available for future testing.

The 1968 report was followed by a report titled "Selection of Poa pratensis L. (Kentucky bluegrass)" by T. P. Riordan, a copy of which is attached to this Final Report as Appendix A. This continues the reporting on the evaluation of superior bluegrass types, and results in a selection of 31 bluegrasses for incorporation into roadside tests. 
This research also investigated the possibility of reducing time and expense involved in breeding and selecting superior uniform types through counting of chromosomes. The thesis proposed was that bluegrasses with low chromosome numbers would be apomictic, resulting in uniform reproduction. Seedlings would remain true to the parent throughout continued seed production. The research concluded that there was little basis to support this proposal. Low chromosome numbers did not serve as a key to selecting uniform apomictic varieties.

Finally, this Final Report reviews selections planted on highway roadsides and their performance and reports a selection of thirteen (13) superior types that will be further evaluated as the initial portion of a new research project in FY 73. Final selections of the bluegrasses to be recommended for seed increase and expanded testing are planned for the spring-summer of 1973 as part of that project. 
APPENDIX A

SELECTION OF POA PRATENSIS L. (KENTUCKY BLUEGRASS)

by

Terrance Patrick Riordan 


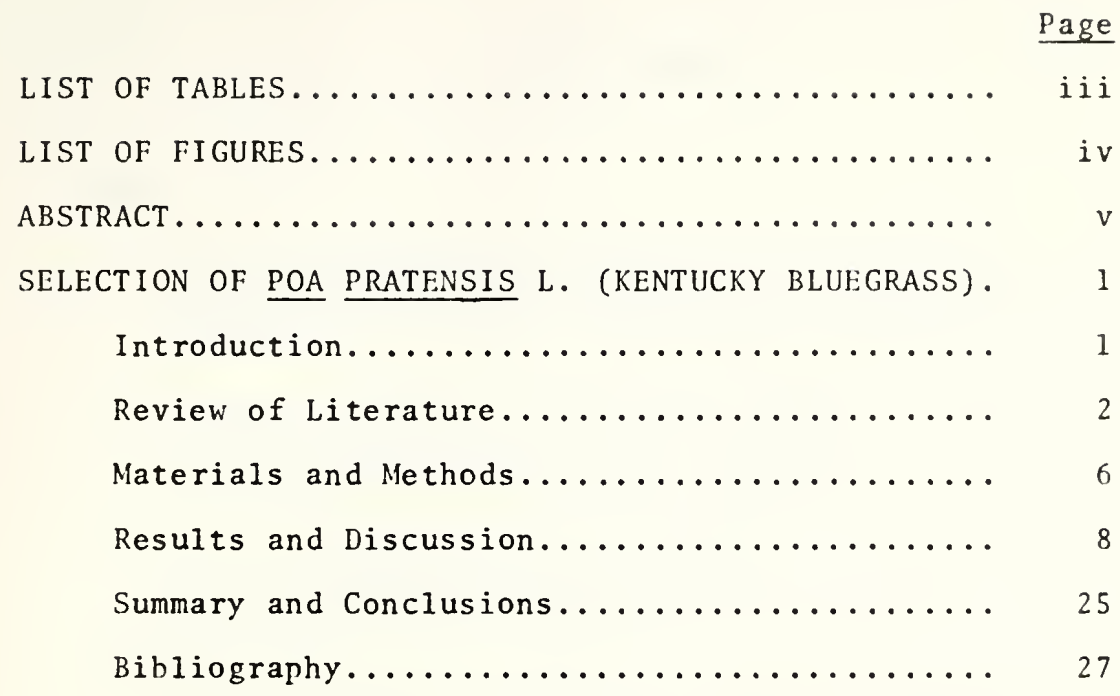




\section{LIST OF TABLES}

Table

1. Means and standard deviations for total population, selected familles, and solocted planta for characterlatics (1lated in order of 1mportance) of exper1ment 1. . . . . . . . . . . . . . . . . . . 9

2. Simple correlation coefficients for total population, selected fantlies, and selected plants for the characteristics of experiment 1. . . . . . . . . 10

3. Selected plants and data for experiment 1, organized from most uniform (appearing apomictic) to most variable (appearing sexual). ............. I4

4. Moans and standand deviations for total population, olectod families, and selocted plants for characterlotics (11sted in onder of 1mportance) of experiment 2. . . . . . . . . . . . . . . . . Is

5. Simple correlation coefficients for total population, selectod famllies, and selected planto for the characteristics of experiment 2. . . . . . . . . 16

6. Selected plants and data for experiment 2, organized from most uniform (appearing apomictic) to most variablo (appearing oexual).

7. Means and standand deviations for total population, selected familles, and selected plants for character1st1ca (11sted in onder of Importance) of experiment 3. ...........................

8. Simple correlation coefficients for total population, selected famflies, and selected plants for the characteristics of experiment 3. . . . . . . . . . . .

9. Soloctod plants and data for experimeont 3, organized from most unfform (appearing apomict1c) to most varlablo (appoaring saxual). 
iv

LIST OF FIGURES

Figure

1
Page

Diagram of methods of developing new apodictic varieties.............. 5 


\section{ABST RACT}

Riordan, Terrance Patrick. Purdue University. Selection of Poa Pratensis L. (Kentucky Bluegrass).

Individual Kentucky bluegrass seedlings in 3 experimental space plantings were rated and measured with the goal selection of types adaptable to roadside utilization. All selections were rated and observed for uniformity in order that outstanding selections could be relegated either to future roadside tests because of uniformity of progeny (apomictic plants) or to future selection tests because of variability of progeny (sexual plants).

All plants were rated for rhizome spread and measured for leaf height. In each experimental planting there was an increase in the amount of rhizome spread and either no change or a slight decrease in leaf height. Other less important characteristics rated and measured were rust resistance; leaf color; winter survival; panicle height, quantity and maturity; seed germination; and seedling height and initial growth.

Simple correlation coefficients were calculated for al1 characters in each experiment. These coefficients indicated that there was a significant negative correlation between rhizome spread and leaf height, while panicle height was generally positively correlated to leaf height and negatively correlated to rhizome spread. 
These results give promise that if leaf height is decreased it may be possible to have lower, more acceptable panicle heights along roadsides. Other correlations indicated that plants with good initial growth had good seed germination, giving a new method of selecting for improved seed germination.

For each of the 3 experimental plantings a list of visually selected plants, arranged from most uniform (apomictic) to most variable (sexual), is given. These lists show the variation available in the plant material which is predominantly from the sexual parent $16 \mathrm{~B}$. 
SEIECTION OF POA PRATENSIS L. (KENTUCKY BLUEGRASS)

\section{Introduct1on}

The purpose of this profect was to eelect Kentucky bluegrase types whose characteristics would meet the necessary requirements of a roadside turf. The requirements considered most important were increased rhizome spread for quick establishment and long-term maintenance of sloping areas, Iow growth habit in order to roduce mowing frequency, plus resistance to disease.

The following example 1llustrates the importance of one of these characters. There are $600 \mathrm{miles}$ of interstate highway system in Indiana, with 18 acres per linear mile, giving a total of 11,000 acres which neod to be mowed 4 cycles each year. At a mowing cost of $\$ 10.00$ per acre, the importance of low growth habit is obvious. In addition to financial considerations, the esthetic and labor-saving value of dwarfness is apparent for home laws and other turfgrass areas.

The Kentucky bluegrass selection program at Purdue University began In 1961, developing into a roadside project in 1965. This project was undertaken with the knowledge that a ouperior turferass would need only to out-perform the combination of native Kentucky bluegrase and tall fescue, and be propagated by seod. This report is a detailed description of the process and results of this effort to develop that grasa. 
Since the sexual bluegrass selection 168 produces many plant types, wide variation was avallable. In 1963 over 100 distinct bluegrass types were selected from the progeny of this single plant. Since selection for variation has been necessary, the sexual progeny of the $16 \mathrm{~B}$ plant material has prodominated in the aucceseive selection program for the last four generations with new germ plasm brought in through pollon of other bluegrass eelections fron universities, Industrial groups, and also other countries. Because of the posslbility of genotype-environment interaction, It is belloved this wide genetic base will be important when the plants judged ouperior under ideal rosearch conditions w1ll be tested under the loas ideal roadaide conditions.

Since the initiation of the roodolde program, over 12,000 individual bluegrass seedlinge have been rated and observod as spaced plants for loaf color, winter ourvival, and panicle characteriatica, as well as the more important characteriatics mentioned earlier.

\section{Revien of Literature}

The ultimate proof of a breeding method is its value in the breedIng of Improved varieties. In Kentucky bluegress, a species known for Its problems with apomixis, methods must be used which eircumvent this breoding problem, and if posolble, use it to advantage. Berry (4) in a 1965 thesis found that broad sense heritability estimates for Kontucky bluegrass wore hlgh, ranging from .84 to .98 , Indicating that the seloction for desired genotypes within a population would be relatively efficient. Calculation of expected genetic advance in percent of the mean Indicated that progress could bo expected through sezection. The expected amount of genetic advance for rhisome spread wes $59 \%$. 
Smith (15) points out the nocessity for understanding the mode of roproduction and soed formation of a species. This is especially important in an apomictic spec1es. Akerberg (1) in 1939 pirat described somat1c apospory as the mechanism of apomixis in Kentucky bluegrass. The cell thet functions as the ombryo sac is formod from non-archesporial tissue in the nucellus, therefore developing directly whout a molotic division. Thus an unroduced ogB is produced parthenogenetically, giving rise, through seed, to a plant genetically identical to the mother plant oven though this plant is highly hoterozygous. Akerberg (3) in 1943 demonstrated that pollination with fertilization of the polar nuclei (pseudogany) is necessary for endosperm and subsequent seod formation. Tinney (17), Akerberg (2), Nielsen (13), and Grazi, et.al. (9) have indicatod that Ientucky bluegrass plants can range from highly sexual where a megaspore results from moiotic divisions, to highly aponictic where the molotically produced megaspnre degenerates and aposporous embryo sacs aro produced. Plants intermediate botween sexual and apomictic may produce both roduced (meiotic) and unroduced (aposporous) egg cells.

Gardner (8) states that saxual plants are nocessary in the development of new and improved strains in a breeding progrem, almost a contradiction in an apomictic species. There is, however, much ovidence that Rentucky bluegrass, though mainiy apomictic, produces some aberrant plants through sexual reproduction. With certain limitations the percent of aberrant plants in the progeny has been used as a measure of sexual reproduction. Akerberg (1) in 1939 found 5.9 to $13.4 \%$ sexual plants in selected families. Seven of the 44 families he used showed wide varietion. Again in 1942 he (2) found that $3.9 \%$ of 79 familles of 5 plants each wore aborrant, and in 9 cases no two plants of the 5 woro alike. 
Tinney and Aanodt (17) found the porcentago of sexual plants ranging from 0 to $21.9 \%$, Brown (6) found from 0.09 to $18.1 \%$ in six aoed loto, and Brittingham (5) found an average of $14.8 \%$ aberrants in 115 progenios, and one seloction had a madmum of $90.5 \%$ aberrants. Gaz1, et.al. (9) In 1961 found that $75.8 \%$ of 800 progeniea derived from singlo panscles appeared to have some aberrant types. They roported tbat the total number of aberrant typeo in the population was 16.5\%, and if only segrogating types were otudied, the figure became 20.5\%. A1so, in the 1968 North Eastern Rogion Turfgrass Report it was mentioned that a selectod clone from Alabama (10) was consistently producing off-types, and that environment did not seen to affect the mode of reproduction of this clone.

In a 1963 thesis Melkerson (12), using comparative measurements and observations showed that there was variation within some bluegrass selections, ospecially 16B. Ho further statod that 16B was particularly valuable because many of its seedlings were vigorous, therefore offering great possibility for the developrent of roadside turf.

Besides the avallability of sexual plants, another problem to the fluing of the genome through recovery of the apondctic meohanism. Studies by Carnahan and Hill (7), Gerstel and Mischanec (10), and Harlan, et.al.(II) on both faculative and obligate apomictic groups have produced data leading to the possible conclusion that the overall process is genetically controlled, and in most groups is recessive to sexuality. It uust be understood, however, that more than one mochansm of apomids mas exdst, thus complicating the efflcient use of apomisis for seed production. 
In 1966 Tallaferro and Bashaw (16) reported tho study of obligate apomixis in buffolgrass, Pennisetum c1lfare, using both solfed and $F_{1}$ progenies. Using a mutant secual plant as the fomale parent, the progeny was claseified for mode of reproduction using ambryo sac analysis or progeny variation. In the $S_{1}$ progeny the sexual to apomictic ratio was not algnificantly different from a $13: 3$, and in the $F_{1}$ progeny the sexual to apomictic ratio was not significantly different from a $5: 3$. Using this information they hypothosized a breoding program using obligate apomixis as means of fluting the genotype in loppoved varieties. The schematic model for this breeding program 1s show in figure 1. The only limitation in this model is the evallability of secual and aponictic plante in the desired opecies.

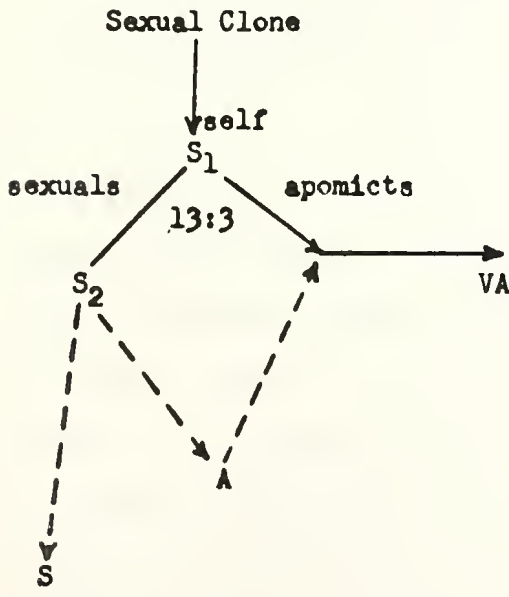

Sexual X Apomict1c

ARIET IES

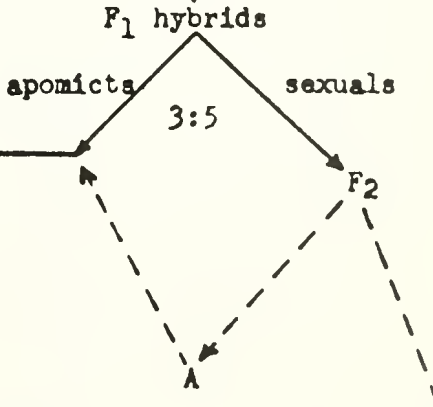

Figure 1. Diagram of methode of developing new apomictic varioties of burfolgrass. 
Materisls and Methods

Three experinental plantings wore made; the first in 1966, the second in 1967, and the third, whlch was a second generation planting fron axperinents 1 and 2, in 1969. Seventy-five percent of the seedlings in each of the three experinents ware derived fron the original sexual plant 16B, whlle the remainder of the material wes from other comercial and experinental sources.

Individual seedlings for the three experiments were grom in $10 x 10$ cm. pots in the greenhouse over winter and then transplanted into the 110ld each spring.

For eech experiment more closely related genetic materials, besed on female parent, were grown together. In experiments 1 and 2, 15 plants $60 \mathrm{cra}$. apart were planted in rows $75 \mathrm{~cm}$. apart. In experiment 3,38 plants of each genetic source and the female parent wero grom in a $1.2 x$ 4.5 plot.

Experiment 1, consisting of 150 selections of 15 plants each (total spaced plants 2250), was measured four times for plant leaf helght, three times for rhizome sproad, and plant panicle holght. These plants wore also rated for leaf color, rust resistance (Pucc1nia graminis), winter survival, and paniclo quantity and maturity. In all cases where ratings were made the range was 1 best to 9 least desired, with 1 being most rhizome spread, darkest leaf color, best rust resistance, best rinter survival, largest paniclo quantity, and earliest panicle maturity. Further information on procedures for measurements and ratings is available. 1

IRiordan, T.P., 1968. "Improvement of Pea pratens1s L. through breeding and selection", M.S. Thesis. Purdue University. 
Exporiment 2, consisting of 200 selections of 15 plants osch (total apaced plants 3000) was moasured for leaf holght, rhizome spread, and pantclo hoight. Rating from 1 to 9 were taken for leaf color, pandclo quantity, and panicle asturity.

Exporimont 3, consisting of 60 solections of 39 plants each (total opaced plants 2340), was measured for leaf holght and rhisome oproad. Ratings wero also mado for leaf color and rust resistanco. Seod lot tosts were made to give ratings on gernatnation and messurements of the average soodling holght, the number of leaves por 10 seodlings, and the number of tillers per 10 seodlings. After a summer growing season each plot (an indiridual selection) was rated for unifomity of the plot, percent plants 11ke the farale parent, and percent dietinct kinds of off-types.

Based on ratings, messurenents and visual judgment, seod was harvested from selected spece plants in experiments 1 and 2 to give materials for the naxt generation planting, experinent 3. Uaing all avallable information from two generations, selections wero frode exporiment 3. Vogetative material was taken from these seloctod plante to provide plants for further selection and roadside testing.

Selected plants were ranked fron those appearing most unlform (apomictio) to those appearing most variable (sexual). In experiment $I$ and 2 thlo ws accomplishod by ranking the average coefficient of variation for the character moaurod and rated, w1th the loast average coefflcient of variation boing the plants appoaring apomictic. In the third experinont selected plante were renked eccording to unlforaity data taken, most uniform considered nost aponictic. 


\section{- Results and Discusaion}

Expordmont 1 (planted 2966) wes the second plant1ng made with the goal of deroloping a rosdelde grass. Past exporience had glven soss 1dea of the characters that should be measured and the time of moasuranent. A 11st of characters studied and the date these masurements or ratings were taken io given in Table 1.

Since no replications of indiridual plants wore made, tests for superiority of individuals wore not made. In ordor to give ome indication of the ralue of data taken and plants selocted, moans and standard doviations of characters of the total population, of selectod familios (ondy familes which included solected plants), and of the soloctod plants withIn familles wero calculatod. These are also given in Table 1.

From the means of rhisome spread data, the most important character measured, it is seen that rhizome spread has increased going from the total population to solocted famlles to selected plants, and that the gresteat change was from selocted familles to aelected plants. These changes cannot be conaldered improvement, since horitability is not 1.0 . Borrg's (4) high estimates for heritabillty (.84 to .98) in Pog prstensis onfs indicate that improvement is posalble.

The moane of loaf hoight show a very ilght increase in loaf longth. Th1s is inconsiutent with the goal that solection was being made for low grouth. This result mas be understood by past f1eld observations shoring that tho character rhfzome sproad and loaf beight wore nogatively correlated, and that during vioual aelection more omphasis had been put on rhizose epread. Thus, for the selooted plents, Increase was found in the character rhlsom spread without chenge in leaf holght. 
Table 1. Woans and standard dovlations for total population, selected samilies, and solected plants for characterlotics (11stod in order of importance) of experiment 1.

\begin{tabular}{|c|c|c|c|c|c|c|}
\hline Character & Date & $\begin{array}{l}\text { Total } \\
(2250 \\
\text { Loan }\end{array}$ & $\begin{array}{l}\text { pop. } \\
\text { plants) } \\
\text { Std.dev. }\end{array}$ & $\begin{array}{l}\text { Sel. } \\
(435 \\
\text { Sean }\end{array}$ & $\begin{array}{l}\text { Fandlies } \\
\text { Plants) } \\
\text { Std.der. }\end{array}$ & $\begin{array}{l}\text { Sol. plants } \\
\text { ( } 31 \text { plants) } \\
\text { Hean Std.der. }\end{array}$ \\
\hline
\end{tabular}

Rhizome

sproad *

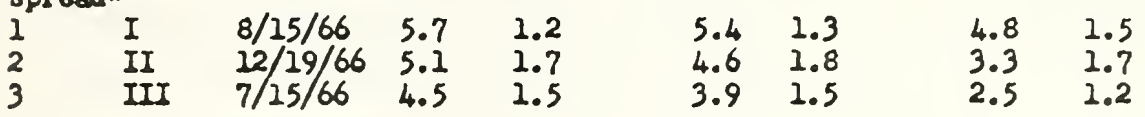

Loal

holght (cmo)

4 I $8 / 15 / 66$ 13. 4.3

5 II $10 / 1 / 66$ 27. 5.6

6 III $4 / 15 / 67$ 17. 6.4

7 IV $8 / 15 / 67$ 21. 4.0

14. 4.5

28. 5.3

19. 8.4

27. 3.8

24. 4.7

18. 5.3

21. 6.2

21. 4.1

Rust

resiatanco*

8

$10 / 15 / 66 \quad 5.6 \quad 1.6$

$5.4 \quad 1.7$

$5.2 \quad 1.9$

Loas

color*

9

$8 / 26 / 66 \quad 4.3 \quad 1.2$

$4.2 \quad 1.2$

$4.3 \quad 1.2$

Winter

survival*

10

$4 / 8 / 67 \quad 2.4 \quad 2.3$

$2.1 \quad 2.1$

$1.4 \quad 1.8$

Pantclo

holght (cmo)

11

$6 / 15 / 67 \quad 53.30$.

55. 27.

60. 25.

Paniclo

quantity

12

$6 / 24 / 67 \quad 4.7 \quad 1.8$

$4.2 \quad 1.9$

$3.3 \quad 1.4$

Pantclo

maturity*

13

$6 / 6 / 67 \quad 4.7 \quad 1.4$

$4.7 \quad 1.3$

$4.4 \quad 1.1$

*liatins $1-9,1$ beot 
There was light increase in the 1mportant charactor of rust resiatance, but at this stage in selection, the lack of resistance has been accepted, if it was on an otherwlso superior plant. This character was measured so that individuals wh good rust resistance could be closely observed in future tests. Selected plants had better winter survival, but usually a superior plant has no winter survival problem; thus the character is considered of linited importance. Leaf color indicated that superior plants could be light green to dark green.

The seedhead characteristics did not change much in the throe plant groups, but these data were taken only as an ald to ruture seed production, so the character were coneldered of less importance in the selection of superior plants.

Simple correlation coefficients among characteristics of experiment 1 are liated in Table 2. They are given for the total population, the selected fandlies, and the selocted plants; signiflcance is given only - for the selected plants $(d f=31)$. The highly significant simple corrolation coefficients for the multiple measurements of rhizome spread and also for the multiple messurements of leaf height are shown, but the lack of higher correlations indicates the possibility of error since no replicates wore available in the spaced plantings. It can be seen that the three measurements of rhizome spread are highly negatively correlated with the four loaf helght measurements. These correlations validate the poor results on the reduction in leaf height when visual emphasis is on rhisome spread. Leaf height IV seems to bo out of line with the other correlations, and it is thought that this is due to collection of data in the middle of the summer (July 15) of the oecond year. 
Table 2. Simple correlation coefficient for total population, selected fanilies, and selected plants for the characteriotics of experiment 1.

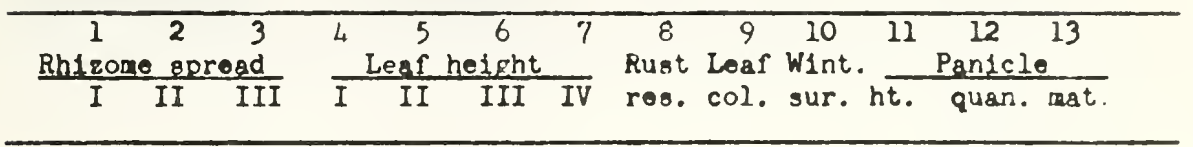

$$
\begin{aligned}
& \begin{array}{llllllllllll}
.77 \quad & .6 ? & -.57 & -.58 & -.50 & -.25 & -.05 & .26 & -.02 & -.43 & .48 & .16
\end{array} \\
& \begin{array}{lllllllllllllll}
1 & 1.0 & .80 & .67 & -.57 & -.57 & -.46 & -.24 & .10 & .40 & .09 & -.48 & .54 & .26
\end{array} \\
& .70 .64-.48-.63-.51-.11-.20 \quad .58-.06-.30 \quad .49-.06 \\
& 2 \quad \begin{array}{lllllllllllll} 
& & .75 & -.43 & -.53 & -.54 & -.30 & .08 & .22 & .14 & -.52 & .60 & .22 \\
& 1.0 & .79 & -.51 & -.58 & -.42 & -.28 & .19 & .32 & .21 & -.52 & .64 & .32
\end{array} \\
& .60-.32-.54-.36 \quad .02-.12 \quad .51 .08-.28 \quad .49 . .15 \\
& 3
\end{aligned}
$$

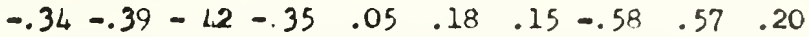

$$
\begin{aligned}
& \begin{array}{lllllllllll}
1.0 & -.37 & -.44 & -.36 & -.29 & .13 & .27 & .19 & -.60 & .52 & .23
\end{array}
\end{aligned}
$$

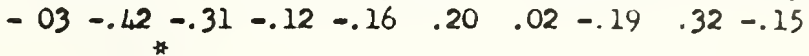

$$
\begin{aligned}
& 4
\end{aligned}
$$

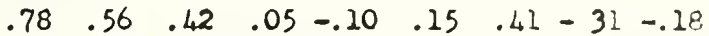

$$
\begin{aligned}
& \begin{array}{lllllllllll}
1.0 & .75 & .53 & .42 & -.13 & -.16 & -.13 & .47 & -.44 & -.29
\end{array}
\end{aligned}
$$

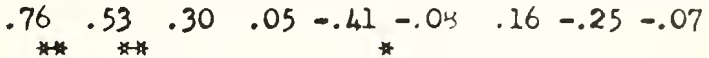

$$
\begin{aligned}
& \begin{array}{rrrrrrrrr} 
& .60 & .48 & .09 & -.10 & .18 & .43 & -.31 & -.17 \\
& .56 & .42 & .04 & -.21 & -.11 & .48 & -.48 & -.26 \\
& .62 & .23 & .27 & -.52 & .00 & .24 & -.38 & .12
\end{array}
\end{aligned}
$$

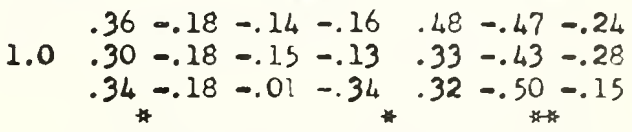

$$
\begin{aligned}
& \begin{array}{lllllll}
-.04 & .06 & .02 & .37 & -.24 & -.21
\end{array} \\
& 7 \\
& 1.0-.12-.13-.10 \quad .34-.27-.18 \\
& -.17 \quad .00 \quad .18 \quad .16-.05-.38 \\
& .00 \quad .21,-.02 \quad .02 \quad .211 \\
& 8 \\
& \begin{array}{llllll}
1.0 & .06 & .25 & -.06 & .13 & .31
\end{array} \\
& \begin{array}{llll}
-.12 \quad .14 \quad .11-.14 \quad .40 & 0
\end{array}
\end{aligned}
$$

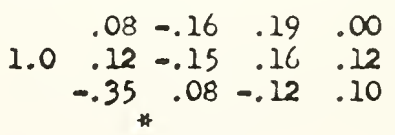

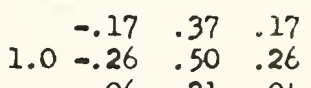

$$
\begin{aligned}
& .06 \quad .21-.04
\end{aligned}
$$


Table 2. (Continued)

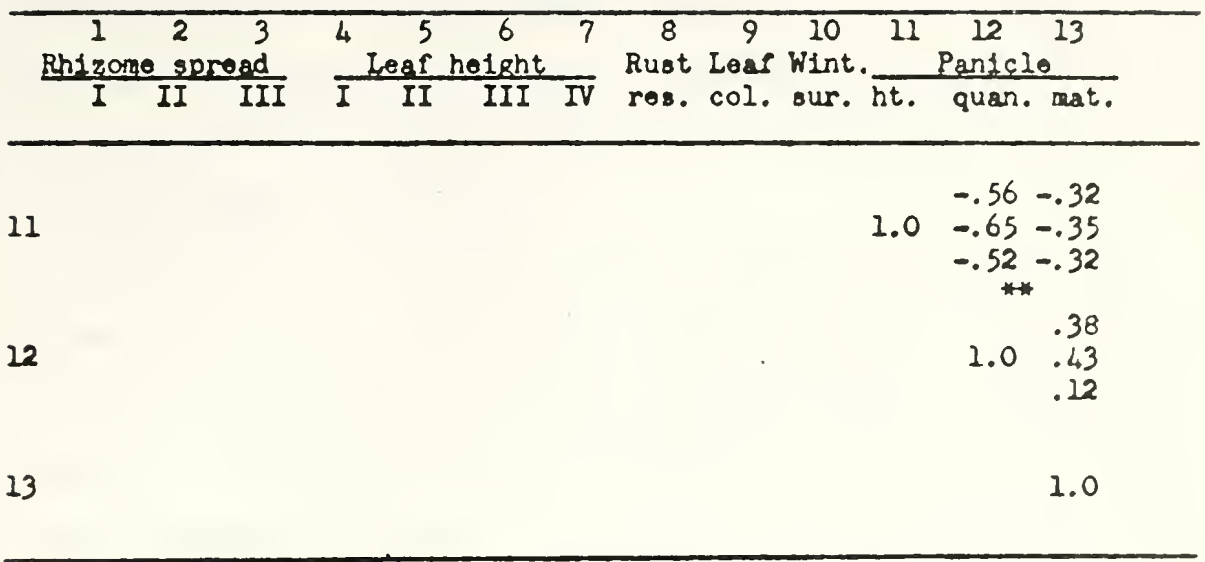

* Signiflcant at the .05 level. * Signiricant at the .01 level. 
Other olgnificant correlations seem to be related to the character panficlo quantity. These correlations indicato that the more rhizome apread and the higher the leaf holght, the greater the panicle quantity; thus sood gleld may possibly be malntained in a low-growlng plant if the rhizome spread is increased.

Table 3 indicates the planto visually selected in this experiment and the data for each. The variation between plants can be seen, and the possibility of solecting a low-growing, rapidly spreading plant ray be onvisioned. This tablo will serve as a reforence later when a study of mode of reproduction is made.

The characters and the date of measurement for experiment 2 are shown in Table 4 along with means and standard deviations of these characters. Again as in exporiment 1 there is increase in rhizome spread goIng from the total population to selocted fandles and to solected plants. Also there is littlo change in leaf height. The means for leaf color and the panicle characters likewise give results comparable to that of exporiment 1.

The simple correlation coefficients are given in Table 5 for the three plant groups and significance is Indicated for the selectod planto $(d r=14)$. Generally correlations are similar to those of experiment 1 , but the significant correlations are reduced due to the smaller number of selected plants. The highly algnificant correlation between the character loaf hoight and paniclo height gives promise of roduced panicle height by reducing leaf hoight. A highly negative correlation is show for the characters panicle height and panicle maturity, which is expected since many common bluegrass types tend to mature early willo turf types tend to mature later, according to field observations. 
Tablo 3. Selected plants and data for experiment 1, organlzed from most uniform (appearing aponictic) to most variable (appearing sexual).

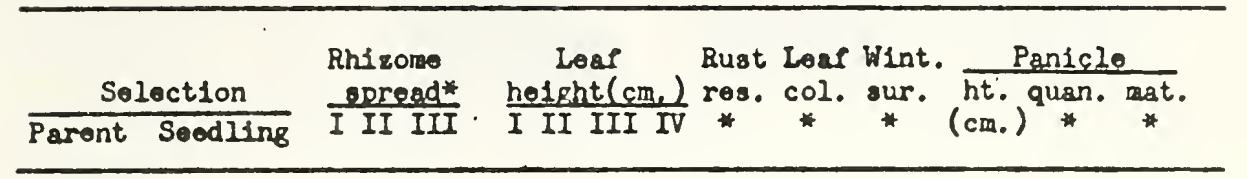

\begin{tabular}{|c|c|c|c|c|c|c|c|c|c|c|c|c|c|c|}
\hline $\begin{array}{l}1 \\
2 \\
3 \\
4 \\
5\end{array}$ & $\begin{array}{l}16 B 1 \\
16 B 9 \\
K 547 \\
110 \\
16 P\end{array}$ & $\begin{array}{c}60-29 \\
8-12 \\
60-32 \\
1-2\end{array}$ & $\begin{array}{l}3 \\
5 \\
5 \\
5 \\
4\end{array}$ & $\begin{array}{l}3 \\
4 \\
4 \\
3 \\
3\end{array}$ & $\begin{array}{l}2 \\
3 \\
4 \\
2 \\
2\end{array}$ & $\begin{array}{ll}18 & 18 \\
20 & 20 \\
15 & 20 \\
15 & 18 \\
12 & 18\end{array}$ & $\begin{array}{l}25 \\
20 \\
20 \\
22 \\
28\end{array}$ & $\begin{array}{r}12 \\
15 \\
15 \\
12 \\
8\end{array}$ & $\begin{array}{l}1 \\
6 \\
5 \\
5 \\
7\end{array}$ & $\begin{array}{l}2 \\
5 \\
4 \\
4 \\
4\end{array}$ & $\begin{array}{l}1 \\
1 \\
1 \\
1 \\
1\end{array}$ & $\begin{array}{l}58 \\
72 \\
48 \\
58 \\
65\end{array}$ & $\begin{array}{l}4 \\
1 \\
4 \\
4 \\
1\end{array}$ & $\begin{array}{ll}4 & \text { Un } 1- \\
5 & \text { form } \\
4 & \uparrow \\
5 & \\
6 & \end{array}$ \\
\hline $\begin{array}{r}6 \\
7 \\
8 \\
9 \\
10\end{array}$ & $\begin{array}{l}16 B 19 \\
16 B 167 \\
110 \\
16 B \\
16 B 9\end{array}$ & $\begin{array}{l}20-4 \\
11-23 \\
20-34 \\
23-19 \\
8-12\end{array}$ & $\begin{array}{l}5 \\
3 \\
5 \\
5 \\
3\end{array}$ & $\begin{array}{l}4 \\
3 \\
4 \\
2 \\
1\end{array}$ & $\begin{array}{l}3 \\
2 \\
2 \\
2 \\
2\end{array}$ & $\begin{array}{ll}12 & 20 \\
20 & 28 \\
15 & 18 \\
15 & 15 \\
22 & 25\end{array}$ & $\begin{array}{l}20 \\
32 \\
20 \\
18 \\
32\end{array}$ & $\begin{array}{r}8 \\
15 \\
10 \\
8 \\
22\end{array}$ & $\begin{array}{l}7 \\
5 \\
6 \\
3 \\
2\end{array}$ & $\begin{array}{l}4 \\
4 \\
4 \\
5 \\
4\end{array}$ & $\begin{array}{l}1 \\
1 \\
1 \\
1 \\
1\end{array}$ & $\begin{array}{l}50 \\
65 \\
65 \\
55 \\
62\end{array}$ & $\begin{array}{l}4 \\
3 \\
4 \\
3 \\
2\end{array}$ & $\begin{array}{l}7 \\
5 \\
5 \\
3 \\
3\end{array}$ \\
\hline $\begin{array}{l}11 \\
12 \\
13 \\
14 \\
15\end{array}$ & $\begin{array}{l}16 B 18 \\
16 B 18 \\
16 B 6 \\
16 B 34 \\
A 10\end{array}$ & $\begin{array}{l}55-24 \\
55-24 \\
31-15 \\
31-24 \\
30-2\end{array}$ & $\begin{array}{l}7 \\
8 \\
3 \\
7 \\
4\end{array}$ & $\begin{array}{l}5 \\
7 \\
1 \\
5 \\
4\end{array}$ & $\begin{array}{l}3 \\
4 \\
2 \\
5 \\
2\end{array}$ & $\begin{array}{rr}5 & 12 \\
8 & 8 \\
12 & 15 \\
22 & 22 \\
15 & 22\end{array}$ & $\begin{array}{r}18 \\
8 \\
12 \\
20 \\
25\end{array}$ & $\begin{array}{r}12 \\
10 \\
10 \\
12 \\
8\end{array}$ & $\begin{array}{l}3 \\
6 \\
4 \\
6 \\
6\end{array}$ & $\begin{array}{l}5 \\
5 \\
5 \\
5 \\
4\end{array}$ & $\begin{array}{l}1 \\
1 \\
1 \\
3 \\
1\end{array}$ & $\begin{array}{l}60 \\
45 \\
65 \\
58 \\
62\end{array}$ & $\begin{array}{l}6 \\
6 \\
1 \\
4 \\
4\end{array}$ & $\begin{array}{l}5 \\
6 \\
4 \\
4 \\
4\end{array}$ \\
\hline $\begin{array}{l}16 \\
17 \\
18 \\
19 \\
20\end{array}$ & $\begin{array}{l}1689 \\
16 \mathrm{~B} 34 \\
16 \mathrm{B1} 18 \\
1689 \\
16 \mathrm{B9}\end{array}$ & $\begin{array}{l}34-18 \\
43-14 \\
11-16 \\
50-31 \\
19-28\end{array}$ & $\begin{array}{l}3 \\
6 \\
4 \\
4 \\
5\end{array}$ & $\begin{array}{l}3 \\
3 \\
3 \\
2 \\
2\end{array}$ & $\begin{array}{l}1 \\
4 \\
3 \\
2 \\
2\end{array}$ & $\begin{array}{rr}12 & 22 \\
14 & 18 \\
18 & 12 \\
18 & 20 \\
8 & 18\end{array}$ & $\begin{array}{r}20 \\
8 \\
12 \\
18 \\
15\end{array}$ & $\begin{array}{r}20 \\
8 \\
8 \\
8 \\
8\end{array}$ & $\begin{array}{l}7 \\
5 \\
6 \\
7 \\
5\end{array}$ & $\begin{array}{l}3 \\
4 \\
4 \\
2 \\
5\end{array}$ & $\begin{array}{l}6 \\
1 \\
1 \\
5 \\
1\end{array}$ & $\begin{array}{l}60 \\
58 \\
62 \\
68 \\
65\end{array}$ & $\begin{array}{l}3 \\
3 \\
3 \\
3 \\
1\end{array}$ & $\begin{array}{l}4 \\
5 \\
4 \\
5 \\
4\end{array}$ \\
\hline $\begin{array}{l}21 \\
22 \\
23 \\
24 \\
25\end{array}$ & $\begin{array}{l}16 \mathrm{B1} \\
16 \mathrm{B1} \\
16 \mathrm{~B} 9 \\
16 \mathrm{~B} 9 \\
110\end{array}$ & $\begin{array}{l}30-14 \\
30-14 \\
38-18 \\
48-31 \\
48-34\end{array}$ & $\begin{array}{l}4 \\
3 \\
5 \\
3 \\
5\end{array}$ & $\begin{array}{l}2 \\
5 \\
3 \\
1 \\
2\end{array}$ & $\begin{array}{l}2 \\
1 \\
3 \\
1 \\
1\end{array}$ & $\begin{array}{ll}15 & 22 \\
15 & 22 \\
12 & 18 \\
12 & 15 \\
10 & 18\end{array}$ & $\begin{array}{l}28 \\
25 \\
18 \\
12 \\
12\end{array}$ & $\begin{array}{r}12 \\
10 \\
8 \\
8 \\
10\end{array}$ & $\begin{array}{l}7 \\
7 \\
2 \\
9 \\
5\end{array}$ & $\begin{array}{l}5 \\
5 \\
4 \\
5 \\
3\end{array}$ & $\begin{array}{l}1 \\
1 \\
5 \\
2 \\
7\end{array}$ & $\begin{array}{l}60 \\
65 \\
55 \\
60 \\
60\end{array}$ & $\begin{array}{l}2 \\
2 \\
5 \\
4 \\
4\end{array}$ & $\begin{array}{l}5 \\
4 \\
5 \\
5 \\
5\end{array}$ \\
\hline $\begin{array}{l}26 \\
27 \\
28 \\
29 \\
30 \\
31\end{array}$ & $\begin{array}{l}110 \\
\text { P19.6 } \\
16 B 1 \\
16 B \\
\text { A10 } \\
16 B 29\end{array}$ & $\begin{array}{l}47-21 \\
30-19 \\
23-14 \\
37-7 \\
20-34 \\
59-15\end{array}$ & $\begin{array}{l}4 \\
4 \\
5 \\
5 \\
6 \\
6\end{array}$ & $\begin{array}{l}1 \\
5 \\
2 \\
4 \\
3 \\
4\end{array}$ & $\begin{array}{l}1 \\
4 \\
2 \\
4 \\
2 \\
5\end{array}$ & $\begin{array}{rr}15 & 25 \\
20 & 18 \\
15 & 22 \\
12 & 18 \\
15 & 25 \\
8 & 18\end{array}$ & $\begin{array}{l}28 \\
15 \\
25 \\
18 \\
25 \\
18\end{array}$ & $\begin{array}{l}10 \\
10 \\
10 \\
10 \\
10 \\
20\end{array}$ & $\begin{array}{l}6 \\
6 \\
5 \\
2 \\
6 \\
6\end{array}$ & $\begin{array}{l}4 \\
3 \\
4 \\
4 \\
4 \\
5\end{array}$ & $\begin{array}{l}1 \\
4 \\
1 \\
1 \\
1 \\
5\end{array}$ & $\begin{array}{l}62 \\
55 \\
60 \\
65 \\
60 \\
68\end{array}$ & $\begin{array}{l}4 \\
4 \\
1 \\
4 \\
4 \\
4\end{array}$ & $\begin{array}{l}5 \\
5 \\
4 \\
2 \\
3 \mathrm{Varl}- \\
2 \mathrm{ablo}\end{array}$ \\
\hline
\end{tabular}

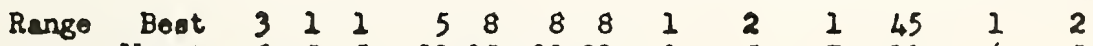
Worst $\begin{array}{lllllllllllll}8 & 5 & 5 & 22 & 25 & 32 & 22 & 9 & 5 & 7 & 72 & 6 & 5\end{array}$ 
Tablo 4. Moens and standand deviations for total population, solectod famlles, and selocted plants for characterist1cs (21sted in order of importance) of experiment 2.

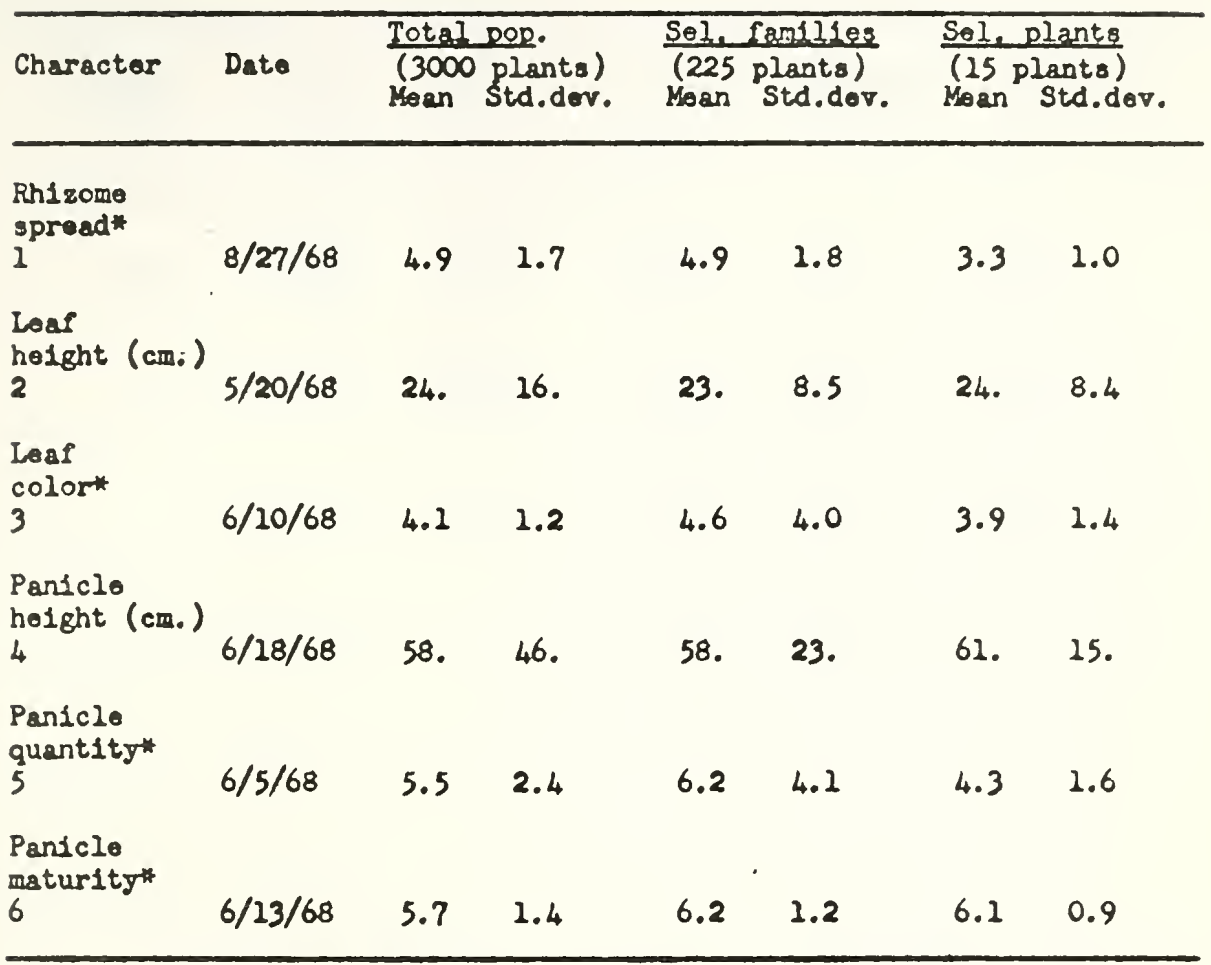

*Rating 1 - 9, 1 bost 
Tablo 5. Simple correlation coofficients for total population, selocted families, and solectod plants for the characteristics of exporiment 2.

\begin{tabular}{|c|c|c|c|c|c|c|}
\hline & $\begin{array}{l}\text { Rhizome } \\
\text { spread } \\
1\end{array}$ & $\begin{array}{l}\text { Leaf } \\
\text { Height } \\
2\end{array}$ & $\begin{array}{c}\text { Loaf } \\
\text { Color } \\
3\end{array}$ & $\begin{array}{c}\text { Height } \\
4\end{array}$ & $\frac{\text { Pandcle }}{\text { Quant } 1 \text { ty }}$ & $\frac{\text { Maturity }}{6}$ \\
\hline 1 & 1.0 & $\begin{array}{l}-.57 \\
-.23 \\
-.22\end{array}$ & $\begin{array}{l}.26 \\
.17 \\
.27\end{array}$ & $\begin{array}{r}-.58 \\
-.04 \\
.29\end{array}$ & $\begin{array}{l}.69 \\
.27 \\
.12\end{array}$ & $\begin{array}{r}.22 \\
.05 \\
-.02\end{array}$ \\
\hline 2 & & 1.0 & $\begin{array}{r}-.06 \\
-.06 \\
.36\end{array}$ & $\begin{array}{l}.93 \\
.54 \\
.88 \\
\end{array}$ & $\begin{array}{r}.20 \\
-.24 \\
-.30\end{array}$ & $\begin{array}{l}-.31 \\
-.52 \\
-.53\end{array}$ \\
\hline 3 & & & 1.0 & $\begin{array}{r}-.13 \\
.64 \\
.33\end{array}$ & $\begin{array}{l}.21 \\
.91 \\
.40\end{array}$ & $\begin{array}{r}-.10 \\
.01 \\
-.11\end{array}$ \\
\hline 4 & & & & 1.0 & $\begin{array}{l}.40 \\
.50 \\
.26\end{array}$ & $\begin{array}{l}-.27 \\
-.53 \\
-.74 \\
\end{array}$ \\
\hline 5 & & & & & 1.0 & $\begin{array}{r}.46 \\
.49 \\
.49\end{array}$ \\
\hline 6 & & & & & & 1.0 \\
\hline
\end{tabular}

\#Significant at the .05 lovel. * Signiflcant at the .01 level. 
In Tablo 6 the variation between plants can be noted, and the possibility of selected plants with certaln characteristics may be visualized. References to this table will be made later when mode of reproduction is studiod.

The characters and date of messurement of experiment 3 and the means and standard devlations for these characters are shown in Table 7. As in the provious experiments an increase in rhizome spread is indicated, but in this case there is a decrease of $1.1 \mathrm{~cm}$. In average leaf height. This has probably been an effect of this experiment's boing the second generation of seloction. The 3 new characters measured (2-3-5) show some difference with a slight increase in the number of leaves and number of t111ors per 10 plants, and also a slightly greater seedling helght.

The characters rust resistance and leaf color show slight change, alnce littlo emphasis was put on them when plante wero visually selected. Rust resistance was measured during a very pronounced infestation, and nearly all familes showed only slight resistance. The character seod germination showed no change in the 3 groupe, indicating that selected plants wero no better or worse than the population as far as this character was concernod. This in itsels is promising since the character is important and possibly seloction of individuals could be used to improve germination. The firal 3 characteristics are tests of variability. The rating for uniformity ( 1 - uniform, 9 - variable) and the percent distinct offypos increased, while the percent of plants like the semale parent docreased, showing the offect of selection for variable plants.

The simplo correlations for the characteristics of the 3 groups of axporimont 3 are given in Tablo $8(\alpha f-61)$. The corrolations aro again olmilar, but with the added information of the now data. 
Table 6. Solectod planto and data for experiment 2, organizod from most uniform (appearing apomictic) to most variable (appearIng sexual).

\begin{tabular}{|c|c|c|c|c|c|c|c|c|c|}
\hline \multicolumn{3}{|c|}{ Selection } & \multirow{2}{*}{$\begin{array}{c}\text { Rh1zome } \\
\text { spread } \\
\end{array}$} & \multirow{2}{*}{$\begin{array}{l}\text { Leaf } \\
\text { height } \\
(\mathrm{cm} .)\end{array}$} & \multirow{2}{*}{$\begin{array}{l}\text { Leaf } \\
\text { color } \\
*\end{array}$} & \multicolumn{3}{|c|}{ Pantcle } & \\
\hline & rent & Seedling & & & & (cm.) & $\begin{array}{c}\text { quant. } \\
\text { * }\end{array}$ & $\begin{array}{c}\text { mat. } \\
*\end{array}$ & \\
\hline $\begin{array}{l}1 \\
2 \\
3 \\
4 \\
5\end{array}$ & $\begin{array}{l}16 \mathrm{BB} 18 \\
16 \mathrm{~B} 18 \\
\text { Bower } \\
16 \mathrm{BB} 86 \\
16 \mathrm{H}\end{array}$ & $\begin{array}{l}80-14 \\
95-22 \\
23-19 \\
13-25 \\
50-1\end{array}$ & $\begin{array}{l}2 \\
4 \\
4 \\
5 \\
3\end{array}$ & $\begin{array}{l}18 \\
25 \\
22 \\
38 \\
32\end{array}$ & $\begin{array}{l}2 \\
5 \\
4 \\
5 \\
6\end{array}$ & $\begin{array}{l}60 \\
70 \\
50 \\
78 \\
82\end{array}$ & $\begin{array}{l}4 \\
2 \\
6 \\
5 \\
6\end{array}$ & $\begin{array}{l}6 \\
5 \\
8 \\
6 \\
5\end{array}$ & Uniform \\
\hline $\begin{array}{r}6 \\
7 \\
8 \\
9 \\
10\end{array}$ & $\begin{array}{l}\times 547 \\
16 \mathrm{BB} 106 \\
16 \mathrm{~B} 84 \\
16 \mathrm{H} \\
16 \mathrm{~B} 72\end{array}$ & $\begin{array}{l}50-26 \\
90-10 \\
90-24 \\
19-18 \\
19-10\end{array}$ & $\begin{array}{l}3 \\
2 \\
5 \\
2 \\
3\end{array}$ & $\begin{array}{l}20 \\
28 \\
20 \\
32 \\
12\end{array}$ & $\begin{array}{l}2 \\
2 \\
3 \\
5 \\
2\end{array}$ & $\begin{array}{l}52 \\
62 \\
68 \\
75 \\
40\end{array}$ & $\begin{array}{l}4 \\
3 \\
5 \\
4 \\
4\end{array}$ & $\begin{array}{l}6 \\
6 \\
6 \\
5 \\
6\end{array}$ & \\
\hline $\begin{array}{l}11 \\
12 \\
13 \\
14 \\
15\end{array}$ & $\begin{array}{l}16 \mathrm{~B} \\
16 \mathrm{~B} 30 \\
16 \mathrm{BB} 76 \\
16 \mathrm{~B} 25 \\
16 \mathrm{~B} 8\end{array}$ & $\begin{array}{l}37-7 \\
21-8 \\
87-3 \\
50-9 \\
24-3\end{array}$ & $\begin{array}{l}4 \\
3 \\
3 \\
4 \\
2\end{array}$ & $\begin{array}{r}22 \\
35 \\
30 \\
25 \\
8\end{array}$ & $\begin{array}{l}5 \\
4 \\
3 \\
5 \\
5\end{array}$ & $\begin{array}{l}58 \\
75 \\
60 \\
62 \\
25\end{array}$ & $\begin{array}{l}6 \\
4 \\
1 \\
4 \\
7\end{array}$ & $\begin{array}{l}6 \\
6 \\
6 \\
6 \\
8\end{array}$ & $\underbrace{}_{\text {Variable }}$ \\
\hline & Rango & $\begin{array}{l}\text { Bost } \\
\text { Worat }\end{array}$ & $\begin{array}{l}2 \\
5\end{array}$ & $\begin{array}{r}8 \\
38\end{array}$ & $\begin{array}{l}2 \\
6\end{array}$ & $\begin{array}{l}25 \\
82\end{array}$ & $\begin{array}{l}1 \\
6\end{array}$ & $\begin{array}{l}5 \\
8\end{array}$ & \\
\hline
\end{tabular}

Fating 1-9, 1 best 
Table 7. Means and standard deviations for total population, selocted families, and selected plante for characteristics (11stod in order of importance) of experiment 3.

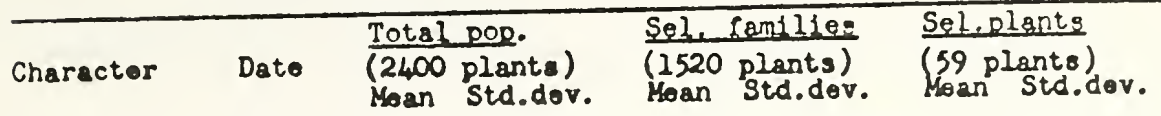

Rhizomo

spread*

1

$10 / 15 / 69 \quad 4.2 \quad 1.5$

$4.0 \quad 1.4$

3.41 .6

No.or tillers/

10 plants

2

$32 / 68$

8.16 .3

8.16 .6

$9.4 \quad 7.9$

No. of leaves/

10 plente 3

$12 / 68 \quad 52 . \quad 13$.

52. 13.

56. 18.

\section{Losf}

helght (cm.)

4

$8 / 20 / 69 \quad 12$. 4.2

12. 4.2

11. 3.8

Seodling

helght (cm.)

5

$11 / 68$

$4.7 \quad 0.9$

$4.8 \quad 0.9$

4.7

0.9

Rust

resistance

6

$9 / 20 / 69 \quad 5.8 \quad 1.6$

$5.7 \quad 1.7$

$5.5 \quad 2.5$

Leat

color

7

$10 / 1 / 69$

$3.8 \quad 1.0$

3.7

0.9

3.51 .0

Seod

germination*

8

$\begin{array}{lll}8 / 15 / 69 & 7.2 & 1.8\end{array}$

$7.2 \quad 1.8$

$7.2 \quad 1.8$

Rating of

unt formity

9

$10 / 69$

3.8

2.9

4.0

3.0

$5.0 \quad 3.1$

$\%$ planto liko

fonale parent

10

$10 / 69$

70. 35.

68. 37.

54. 37.

8 distinct

offtypes

11

$10 / 69$

23. 25.

24. 25.

26. 24 . 
Tablo 8. Simplo correlation coefficients for total population, selected fandlies, and selected plants for the characteristics of experiment 3.

\begin{tabular}{|c|c|c|c|c|c|c|c|c|c|c|c|}
\hline & 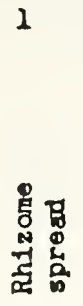 & 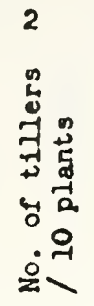 & 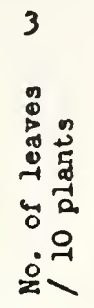 & 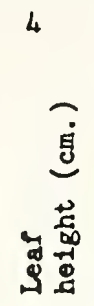 & 5 & 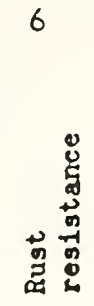 & 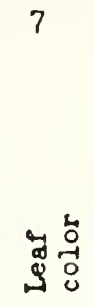 & 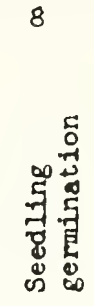 & 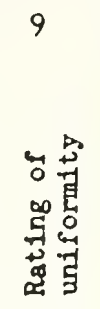 & 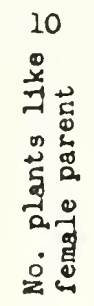 & 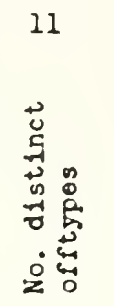 \\
\hline 1 & 1.0 & $\begin{array}{r}-.02 \\
.10 \\
-.06\end{array}$ & $\begin{array}{r}-.04 \\
.02 \\
-.11\end{array}$ & $\begin{array}{l}-.36 \\
-.36 \\
-.21\end{array}$ & $\begin{array}{l}-.18 \\
-.04 \\
-.13\end{array}$ & $\begin{array}{l}.25 \\
.21 \\
.14\end{array}$ & $\begin{array}{l}.03 \\
.20 \\
.40 \\
\end{array}$ & $\begin{array}{l}.08 \\
.09 \\
.00\end{array}$ & $\begin{array}{l}.32 \\
.31 \\
.00\end{array}$ & $\begin{array}{l}-.31 \\
-.34 \\
-.05\end{array}$ & $\begin{array}{r}.12 \\
.13 \\
.34\end{array}$ \\
\hline 2 & & 1.0 & $\begin{array}{r}.82 \\
.83 \\
.93\end{array}$ & $\begin{array}{r}.10 \\
-.01 \\
-.25\end{array}$ & $\begin{array}{l}-.20 \\
-.35 \\
-.40 \\
\end{array}$ & $\begin{array}{r}-.02 \\
-.08 \\
.00\end{array}$ & $\begin{array}{l}-.13 \\
-.15 \\
-.22\end{array}$ & $\begin{array}{l}.35 \\
.45 \\
.54 \\
\end{array}$ & $\begin{array}{r}-.01 \\
.00 \\
.20\end{array}$ & $\begin{array}{r}.03 \\
.00 \\
-.17\end{array}$ & $\begin{array}{l}.28 \\
.47 \\
.57\end{array}$ \\
\hline 3 & & 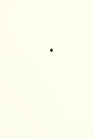 & 1.0 & $\begin{array}{r}.10 \\
.03 \\
-.19\end{array}$ & $\begin{array}{l}-.28 \\
-.36 \\
-.39 \\
-\end{array}$ & $\begin{array}{l}-.15 \\
-.27 \\
-.15\end{array}$ & $\begin{array}{l}-.12 \\
-.10 \\
-.14\end{array}$ & $\begin{array}{l}.39 \\
.48 \\
.57 \\
\end{array}$ & $\begin{array}{l}.02 \\
.04 \\
.27\end{array}$ & $\begin{array}{r}.01 \\
-.02 \\
.22\end{array}$ & $\begin{array}{l}.12 \\
.24 \\
.48\end{array}$ \\
\hline 4 & & & & 1.0 & $\begin{array}{r}-.01 \\
-.15 \\
-.28\end{array}$ & $\begin{array}{r}-.19 \\
-.28 \\
-.17\end{array}$ & $\begin{array}{l}-.21 \\
-.22 \\
-.13\end{array}$ & $\begin{array}{r}-.02 \\
.03 \\
-.12\end{array}$ & $\begin{array}{l}-.42 \\
-.40 \\
-.63 \\
t \rightarrow 4\end{array}$ & $\begin{array}{l}.48 \\
.52 \\
.71 \\
\end{array}$ & $\begin{array}{l}-.14 \\
-.05 \\
-.19\end{array}$ \\
\hline 5 & & & & & 1.0 & $\begin{array}{l}.08 \\
.17 \\
.09\end{array}$ & $\begin{array}{r}.26 \\
.29 \\
.32 \\
\end{array}$ & $\begin{array}{r}-.25 \\
-.15 \\
-.27\end{array}$ & $\begin{array}{l}.21 \\
.41 \\
.36 \\
\end{array}$ & $\begin{array}{l}-.28 \\
-.47 \\
-.44 \\
\end{array}$ & $\begin{array}{r}.12 \\
.26 \\
-.06\end{array}$ \\
\hline 6 & & & & & & 1.0 & $\begin{array}{l}.09 \\
.22 \\
.10\end{array}$ & $\begin{array}{l}-.09 \\
-.06 \\
-.06\end{array}$ & $\begin{array}{l}.17 \\
.19 \\
.11\end{array}$ & $\begin{array}{l}-.14 \\
-.17 \\
-.12\end{array}$ & $\begin{array}{l}.00 \\
.08 \\
.41\end{array}$ \\
\hline 7 & & & & & & & 1.0 & $\begin{array}{l}-.04 \\
-.02 \\
-.04\end{array}$ & $\begin{array}{r}.15 \\
.09 \\
-.06\end{array}$ & $\begin{array}{l}-.25 \\
-.23 \\
-.10\end{array}$ & $\begin{array}{l}.17 \\
.19 \\
.24\end{array}$ \\
\hline 8 & & & & & & & & 1.0 & $\begin{array}{r}.00 \\
-.01 \\
.03\end{array}$ & $\begin{array}{r}-.01 \\
.02 \\
.00\end{array}$ & $\begin{array}{l}.21 \\
.11 \\
.29\end{array}$ \\
\hline
\end{tabular}


Table 8. (Continuod)

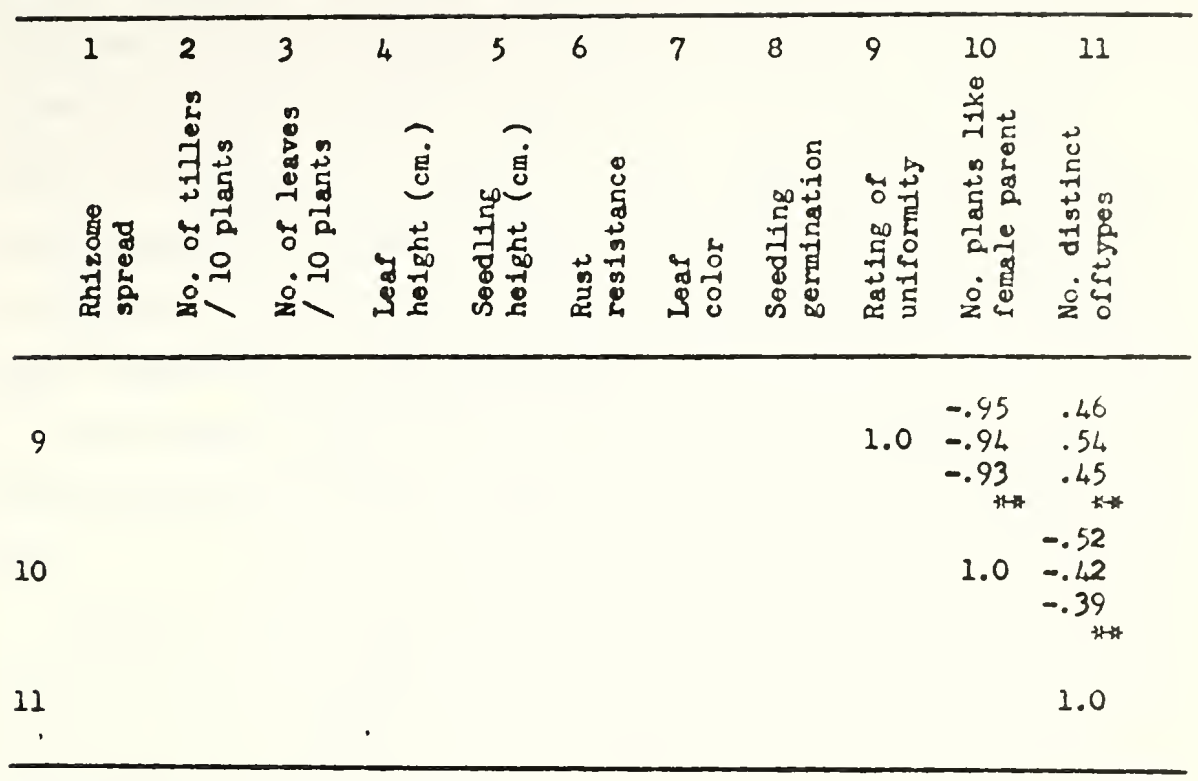

*Significant at the .05 level. * Significant at the .01 levol. 
The number of loaves per 10 plants and number of tillers per 10 plants are highly positively correlated, and they are both positively correlated with seod germination; a plant that produces a lot of oarly vegetative growth has good sood germination or vice versa. Seedifing helght was meesured as a prediction of leaf height, but these measurenents show a negative correlation, evidently reducing the effoctiveness of earIy prodiction. The three tests of uniformity show significant correlations, adding value to these measurements.

The visually selected plants and thelr data are given in Table 9. These plants wll be used in roadside planting and in future selection work.

Tables 3, 6, and 9 are 11sts of the selected plants for the two proIfminary selection experiments and the second generation selection experiment respectively. These threo lists are arranged in order from the plant appearing most apomictic to the plant appearing most sexual. In Table 9 the last column containg the rank in average coefficient of variation of the previous generstion. (1-28; experiment one, plant 28 - appearing variable). Some plants do not have this information because they vere not tested in a previous generation. The normal trend is that uniform plants beget uniform, and sexual beget sexual, but with certain axceptions such as solections 1-4, the 16B-1 material. This information possibly w1l allow superior unfform plants of two generations to be moved directly Into roadside tests due to the possible apomictic character, whlle variable plants are used for further teoting and solection. 
Table 9. Selected plants and data for axperimont 3, organizod from most uniform to most variable.

1. Rhirome spread*I

2. No. of tillers / 10 planto

3. No. of leaves 10 planto

4. Loaf height (cm.)

5. Soodling holght (cm.)

6. Rust rosistance*
7. Loaf color

8. Seodling germination *

9. Rating of uniformity*

10. No. of plants l1ko famale paront

il. No. of distinct offtypes

12. Rank of averago C.V. in first generation

\section{Parent Soloction}

$\begin{array}{llllllllllll}1 & 2 & 3 & 4 & 5 & 6 & 7 & 8 & 9 & 10 & 11 & 12\end{array}$

\begin{tabular}{|c|c|c|c|c|c|c|c|c|c|c|c|c|}
\hline $\begin{array}{l}16 \mathrm{BI} \\
16 \mathrm{BI} \\
16 \mathrm{BI} \\
16 \mathrm{BI} \\
16 \mathrm{BI}\end{array}$ & $\begin{array}{l}23-14 \\
23-14 \\
30-14 \\
30-14 \\
60-29\end{array}$ & $\begin{array}{l}3 \\
3 \\
2\end{array}$ & $\begin{array}{l}4 \\
4 \\
2 \\
3 \\
5\end{array}$ & $\begin{array}{l}41 \\
36 \\
39 \\
38 \\
53\end{array}$ & $\begin{array}{ll}12 & 3.7 \\
15 & 4.0 \\
18 & 4.8 \\
15 & 4.0 \\
27 & 5.2\end{array}$ & $\begin{array}{l}2 \\
9 \\
8 \\
8 \\
3\end{array}$ & $\begin{array}{l}2 \\
4 \\
4 \\
4 \\
3\end{array}$ & $\begin{array}{l}3 \\
5 \\
4 \\
4 \\
6\end{array}$ & $\begin{array}{l}1 \\
1 \\
1 \\
1 \\
1\end{array}$ & $\begin{array}{l}39 \\
39 \\
39 \\
39 \\
39\end{array}$ & $\begin{array}{l}0 \\
0 \\
0 \\
0 \\
0\end{array}$ & $\begin{array}{l}1-28 \\
1-28 \\
1-21 \\
1-22 \\
1-1\end{array}$ \\
\hline $\begin{array}{l}16 \mathrm{~B} 6 \\
16 \mathrm{Bg} \\
16 \mathrm{~B} 9 \\
16 \mathrm{BB} 10 \\
16 \mathrm{~B} 18\end{array}$ & $\begin{array}{l}-15 \\
-12 \\
-12 \\
-14 \\
-22\end{array}$ & & $\begin{array}{r}5 \\
9 \\
8 \\
23 \\
14\end{array}$ & $\begin{array}{l}46 \\
58 \\
65 \\
76 \\
59\end{array}$ & $\begin{array}{ll}15 & 5.0 \\
16 & 4.7 \\
14 & 4.2 \\
14 & 3.0 \\
10 & 3.9\end{array}$ & $\begin{array}{l}8 \\
2 \\
2 \\
3 \\
6\end{array}$ & & & $\begin{array}{l}1 \\
1 \\
1\end{array}$ & & $\begin{array}{l}0 \\
0 \\
0 \\
0 \\
0\end{array}$ & $\begin{array}{l}1-6 \\
1-2 \\
1-10 \\
2-1 \\
2-2\end{array}$ \\
\hline $\begin{array}{l}\text { 8547 } \\
16836 \\
168 B 76 \\
168 B 106 \\
110\end{array}$ & & $\begin{array}{ll}4 & 2 \\
3 & \\
3 & \\
5 & \\
4 & 1\end{array}$ & $\begin{array}{r}29 \\
5 \\
7 \\
8 \\
13\end{array}$ & $\begin{array}{l}82 \\
66 \\
48 \\
43 \\
65\end{array}$ & $\begin{array}{ll}12 & 3.6 \\
16 & 4.0 \\
12 & 5.2 \\
10 & 3.7 \\
11 & 5.0\end{array}$ & $\begin{array}{l}6 \\
2 \\
7 \\
6 \\
5\end{array}$ & $\begin{array}{l}3 \\
5 \\
2 \\
4 \\
4\end{array}$ & & $\begin{array}{l}1 \\
1 \\
1 \\
1 \\
1\end{array}$ & $\begin{array}{l}39 \\
39 \\
39 \\
39 \\
39\end{array}$ & $\begin{array}{l}0 \\
0 \\
0 \\
0 \\
0\end{array}$ & $\begin{array}{l}2-6 \\
2-13 \\
2-7 \\
1-15\end{array}$ \\
\hline $\begin{array}{l}\mathrm{K} 547 \\
16829 \\
16 \mathrm{B18} \\
\text { Athens } \\
\text { 16B9 }\end{array}$ & & $\begin{array}{l}4 \\
3 \\
4 \\
4\end{array}$ & $\begin{array}{r}3 \\
1 \\
13 \\
8 \\
5\end{array}$ & $\begin{array}{l}48 \\
44 \\
43 \\
53 \\
37\end{array}$ & $\begin{array}{ll}18 & 3.8 \\
15 & 3.7 \\
12 & 6.9 \\
11 & 4.7 \\
11 & 4.4\end{array}$ & $\begin{array}{l}8 \\
3 \\
7 \\
7 \\
8\end{array}$ & $\begin{array}{l}5 \\
3 \\
4 \\
5\end{array}$ & $\begin{array}{l}8 \\
3 \\
7 \\
7 \\
8\end{array}$ & $\begin{array}{l}1 \\
2 \\
2 \\
2 \\
2\end{array}$ & $\begin{array}{l}39 \\
37 \\
37 \\
37 \\
36\end{array}$ & $\begin{array}{l}0 \\
1 \\
2 \\
2 \\
2\end{array}$ & $\begin{array}{l}\overline{I-31} \\
1-12 \\
\overline{I-23}\end{array}$ \\
\hline $\begin{array}{l}16 \mathrm{BB} 5 / x 21 \\
\text { WSLD } \\
16 \mathrm{~B} 9 \\
16 \mathrm{BB} 86 \\
16 \mathrm{~B} 24 \times \mathrm{B} 171\end{array}$ & $\begin{array}{l}38-18 \\
13-25 \\
104-28\end{array}$ & $\begin{array}{l}8 \\
3\end{array}$ & $\begin{array}{r}10 \\
1 \\
12 \\
1 \\
6\end{array}$ & $\begin{array}{l}43 \\
57 \\
40 \\
50\end{array}$ & $\begin{array}{rl}17 & 4.7 \\
10 & 5.4 \\
11 & 3.5 \\
13 & 5.4 \\
9 & 5.8\end{array}$ & $\begin{array}{l}5 \\
5 \\
9 \\
6\end{array}$ & $\begin{array}{l}3 \\
2 \\
3\end{array}$ & $\begin{array}{l}9 \\
9 \\
6 \\
0\end{array}$ & $\begin{array}{l}2 \\
3 \\
3 \\
4 \\
4\end{array}$ & $\begin{array}{l}35 \\
30 \\
30 \\
20 \\
12\end{array}$ & $\begin{array}{l}3 \\
4 \\
5 \\
5 \\
4\end{array}$ & $\begin{array}{l}1-16 \\
2-4 \\
\end{array}$ \\
\hline
\end{tabular}


Tablo 9. (Continued)

Sarent Solection
Soeding

$\begin{array}{llllllllllll}1 & 2 & 3 & 4 & 5 & 6 & 7 & 8 & 9 & 10 & 11 & 12\end{array}$

$2616 \mathrm{~B} 24 \times \mathrm{B} 171 \quad 104-28$

27

$50-31$

$\begin{array}{rrrr}3 & 6 & 50 & 9 \\ 1 & 9 & 49 & 13\end{array}$

5.89

5

$\begin{array}{rrrrl}9 & 4 & 12 & 5 & = \\ 7 & 5 & 20 & 7 & 1-19 \\ 6 & 5 & 6 & 6 & = \\ 6 & 5 & 6 & 6 & = \\ 6 & 5 & 6 & 6 & =\end{array}$

$\begin{array}{ll}28 & 16 \mathrm{BB} 172 \\ 29 & 16 \mathrm{BB} 172\end{array}$

$\begin{array}{lllll}74-13 & 3 & 10 & 55 & 10\end{array}$

4.47

$74-13$

5 10 $55, ?$

5.66

$74-13$

$\begin{array}{ll}5.6 & 6 \\ 5.6 & 6\end{array}$

$24-3$

$19-28$

$\begin{array}{llll}\frac{1}{6} & - & -12\end{array}$

- 6

2

$\begin{array}{llll}6 & 25 & 5 & 2-15 \\ 6 & 25 & 8 & 1-20 \\ 6 & 20 & 8 & 2-12 \\ 6 & 20 & 8 & 2-12 \\ 6 & 20 & 8 & 2-12\end{array}$

$\begin{array}{ll}34 & 16830 \\ 35 & 16830\end{array}$

$21-8$

$\begin{array}{llll}1 & 2 & 41 & 12\end{array}$

5.46

38

$36 \quad 16834$

21-8

$\begin{array}{llllll}3 & 2 & 41 & 12 & 5.4 & 6\end{array}$

$\begin{array}{ll}3 & 6 \\ 2 & 6\end{array}$

$\begin{array}{lllllll}43-14 & 3 & 5 & 37 & 11 & 5.7 & 7\end{array}$

$\begin{array}{llllll}2 & 5 & 7 & 15 & 8 & 1-17\end{array}$

$37 \quad 26834$

$\begin{array}{lllll}43-14 & 2 & 5 & 37 & 10\end{array}$

5.77

25

$7 \quad 15$

$\begin{array}{lllllll}43-14 & 4 & 5 & 37 & 7 & 5.7 & 7\end{array}$

$1-17$

$\begin{array}{lllllll}19-10 & 4 & 2 & 40 & 7 & 5.9 & 7\end{array}$

35

$\begin{array}{llll}7 & 15 & 8 & 1-17\end{array}$

$39 \quad 16872$

23-19

41355

$19-18$

$\begin{array}{llllll}4 & 6 & 50 & 6 & 5.8 & 5\end{array}$

4

$\begin{array}{llll}7 & 10 & 10 & 2-10\end{array}$

$4116 \mathrm{H}$

$42 \quad 16 \mathrm{H}$

$19-18$

3650

45

$11-8$

$\begin{array}{lll}4 & 27 & 99\end{array}$

$44 \quad 16 \mathrm{~B} 42$

$11-8$

$\begin{array}{ll}327 & 99\end{array}$

$11-8$

$\begin{array}{lll}4 & 27 & 99\end{array}$

$\begin{array}{lll}6 & 5.85\end{array}$

3

$45 \quad 16 B 42$

$11-8$

$\begin{array}{llll}1 & 27 & 99 & 12\end{array}$

$46 \quad 16 \mathrm{~B} 42$

11-8

$\begin{array}{lll}1 & 27 & 99\end{array}$

$11-8$

$\begin{array}{lll}3 & 27 & 99\end{array}$

$48 \quad 16 B 42$

49 16B55

$86-26$

21167

$50 \quad 16 \mathrm{~B} 55$

$86-26$

11167

51. 16B55

52 16B55

53 16B25

54 16B25

55 26B25

$86-26$

$\begin{array}{lllllll}86-26 & 3 & 8 & 67 & 8 & 4.8 & 6 \\ 86-26 & 1 & 7 & 67 & 7 & 4.8 & 6\end{array}$

$\begin{array}{lllllll}50-9 & 4 & 8 & 57 & 8 & 4.6 & 6\end{array}$

$\begin{array}{lllllll}50-9 & 2 & 10 & 57 & 10 & 4.6 & 6\end{array}$

$\begin{array}{lllllll}50-9 & 4 & 13 & 57 & 13 & 4.6 & 6\end{array}$

$56 \quad 16 \mathrm{~B} 9$

48-31

$\begin{array}{llll}3 & 14 & 52 & 13\end{array}$

$\begin{array}{lllll}54-1 & 3 & 1 & 41 & 10\end{array}$

$54-1$

5.15

52

$58 \quad 16 \mathrm{H}$

59 Plque

$30-19$

6

Beet

Rango

Woret

12999

9927

277.2

2

*Rating $1-9,1$ bost

\begin{tabular}{l}
$8 \quad 36 \quad 6 \quad 3.69259293915$ \\
\hline
\end{tabular}

I(Rating 1, opread $48 \mathrm{~cm}$, or mores rating 9, sprosd $12 \mathrm{am}$ or $20 \mathrm{~s}$ ) 


\section{Summary and Conclustions}

Over 12,000 Ind1Fldual Kentucks bluegress seodlings were rated and measured with the goal of solection of types adaptable to roadside utilization. Two preliminary experimental plantings and a later third planting, which included mainly the selected plant material from the firat generation experiments, were made.

All plants were rated for rhlzome spread and mosured for leaf height. In addition to these more important characteristica, other ratings and moasurements were made in each experiment. In experiment 1 rust resistance, leaf color, winter survival, and the panicle characteristics; in experiment 2 leaf color and paniclo characteristico; and in axporiment 3 rust resistance, leaf color, seod germination, and seodling characteristics vere rated or moasured. In experiment 3 selections consisting of 38 spaced plants and the parent clone were ratod and measured for uniformaty.

Selection done in each experiment was based predominantly on visual observation. Means and standard devlations of selected planta were compared to those of selected families and the total population. In each experiment there was an increase in the amount of rhizome spread among the selected plants with little, if any, increase in leaf holght. This is considered acceptable due to the algnificant negative correlation which was later calculated for the two characters. In experiment 3, the second generation of solection, there was a slight decrease in loaf holght, giving promise for future decrease in this character.

Simple correlation coefficiente wore calculated for all charactors in oach axperiment. In addition to the algnificant negative correlation 
found botween loof helght and rhlzomo spread, panicle height was generalIf positively corrolated with lear height and negatively correlated whth rhizome spread. This indicates that if leaf height is reduced in future generations of selection, it may be possibla to have larer, more acceptablo pantcle helghts along roadsides. In experiment 3 the significant simple correlation coefficients of the seodling characteristics showed that plants with increased initial growth (leaves and t1liers) also had good seed germination or vice versa. These characteristics are considered Important for roadside establishment. The positive relationship gives promise that selection of plants which had good inftial growth would also have good seed germination. The negative correlation of seedling height and lear hoight indlcated that the early measurement is not a good prediction of lesf height. Other tests of this relationship should be made since early prodiction of leaf helght would be valuable.

For each experiment the visually selected plants are listed. The I1sts are included to indicate the varlability available within the I6B plant material for future hybridization. These lists of selected plants were each organized from the most uniform plant to the most variable plant. It is belleved that uniform plants, due to the possible apomictic mode of reproduction, are ready for roadside testing and plant increase (both vegetative and seed), whlle variable plants, due to the poseible sexusl mode of reproduction, are considered part of the select1on program. 


\section{Bibliograghr}

1. Akerberg, E. 1939. Apomictic and soxual sood. formation in Pos pratensis. Herodites 25:359-370.

2. Akerberg, E. 1942. Cytogenot1c Studios in Pos pratengis and 1ts hybrid with Pos alping. Hereditas 28:1-126.

3. Akerberg, B. 1943. Further studies of the embryo and ondosperm development in Poo pratens1s. Herod1tas 29:198-201.

4. Berry, C.D. 1965. Variance and covarlance componente of quant1tative turf characters of Poo pratensis L. M.S. Thesis; Rurdue Oniveraity.

5. Brittinghan, W.H. 1943. Type of seod formation as Indicatod by the nature and extent of variation in Rentucky bluegraso and 1ta practical implications. Jour. Agr. Bes. 67:225-264.

6. Brown, W.L. 1941. The cytogenet1cs of Pog pratensis. Ann. Mo. Bot. Garden. 28:439-522.

7. Carnahan, H.L. and H.D. H1Il. 1961. Cytolog and genetics of forage grasess. Bot. Rov. 27:1-62.

8. Gardner, E.J. 1946. Selection in solf-pollinated lines of Bromus inernis Leyss, Postuca elstior L. and Dsctylis glomerata $\mathrm{L}$. J. Amer. Soc. Agron. 38:264-272.

9. Gaz1, Y., M. Umaerus, and E. Akerberg. 1961. Observations on the mode of reproduction and the embryology of Pon pretensis. Heroditas $47: 489-541$.

10. Gerstel, D.V. and W. Machanec. 1950. On the 1nheritance of apomixi. In Guarule. Bot. Gaz. 115;89-93.

11. Harlan, J.B. and J.M.J. deWet. 1963. Role of apomixis in the erolution of the Bothelechloa-Dichanthium complox. Crop Sc1. 3:314316.

12. Molkerson, E.J. 1963. Comparative performance of vogetative and sodling bluegrasses for turs. M.S. Thes1s; Purdue UnIversity. 
13. Niolsen, E.L. 1945. Cytology and breoding behavior of solocted plants of Pos pretens1s. Bot. Gaz. 206:357-382.

14. North Eastorn Regional Turfgrass Report. 1968. New Jersey-57.

15. Snlth, D.C. 1944. Pollination and seed formation in grasses. Jour. Agr. Res. 66:78-95.

16. Tallaforro, C.M. and E.C. Bashaw. 1966. Inheritance and control of obligat. apomixis in breoding buffelgrass. Crop Sc1. 6;473476.

17. Tinney, F.W. 1940. Cytology of parthenogenesis in Poa protensis. Jour. Agr. Res. 60:351-360. 
